\title{
Identification keys to murid rodents of Argentina
}

\author{
Pablo Teta ${ }^{1}$, and J. Pablo Jayat ${ }^{2 *}$ \\ 1 División Mastozoología, Museo Argentino de Ciencias Naturales "Bernardino Rivadavia”. Ciudad Autónoma de Buenos Aires. \\ Buenos Aires, Argentina. E-mail:antheca@yahoo.com.ar (PT). \\ ${ }^{2}$ Unidad Ejecutora Lillo (CONICET-Fundación Miguel Lillo), San Miguel de Tucumán. Tucumán, Argentina. E-mail: eljayat@gmail. \\ com (JPJ). \\ *Corresponding author
}

\begin{abstract}
Muroid rodents are the most species-rich superfamily of rodents occurring in Argentina. Increased fieldwork with these mammals depicts the need of adequate keys to identify species on the base of external characters. In this contribution we provide three keys (one for families and subfamilies, and another two for Sigmodontinae and Muridae, respectively) for all known species of Cricetidae and Muridae distributed in Argentina (42 genera and 110 species). In addition to the dichotomous keys, and as a way to facilitate the identification, we include for each species a brief description of its distribution and the main habitats where it occurs.

Los roedores muroideos constituyen la superfamilia de roedores con más especies en Argentina. El creciente interés en el trabajo de campo con estos mamíferos ha puesto en evidencia la necesidad de contar con claves para identificar sus especies a partir de características externas. En esta contribución se proporcionan tres claves (una para familias y subfamilias y otras dos para Sigmodontinae y Muridae) para todas las especies conocidas de Cricetidae y Muridae que se distribuyen en Argentina (42 géneros y 110 especies). Además de las claves dicotómicas, y como una forma de facilitar la identificación, para cada especie incluimos una breve descripción de su distribución y de los principales hábitats en donde ocurre.
\end{abstract}

Keywords: Cricetidae, integument, Muridae, Sigmodontinae, taxonomic identification.

๑ 2021 Asociación Mexicana de Mastozoología, www.mastozoologiamexicana.org

\section{Introducción}

La superfamilia Muroidea constituye el grupo de roedores con más especies en el Nuevo Mundo. En Argentina están representados por dos familias, Cricetidae y Muridae (introducida); la primera incluyendo dos subfamilias, Arvicolinae (introducida) y Sigmodontinae (nativa). Su diversidad abarca desde formas anfibias hasta arborícolas, cursoriales o semifosoriales (e. g., Voss 1988; Carrizo et al. 2014), con hábitos tróficos que van desde la herbivoría más o menos estricta hasta la omnivoría y animalivoría (e. g., Voss 1988; Maestri et al. 2016; Verde Arregoitia y D'Elía 2020). Al igual que otros pequeños mamíferos, los muroideos desempeñan un papel fundamental en las redes tróficas, donde actúan como presas de otros vertebrados, contribuyendo al flujo de energía y nutrientes (Lacher et al. 2017). Muchas especies ocupan nichos ecológicos especializados y proporcionan funciones importantes a los ecosistemas, como la remoción de suelos y la dispersión de semillas (Lacher et al. 2017). A su vez, algunas de ellas también son vectores de zoonosis, algunas de elevada mortalidad, como el virus Hanta, y plagas de muchos cultivos (Pardiñas et al. 2017). Por todo esto, su importancia para los seres humanos no ha pasado desapercibida, transformándose en uno de los grupos más estudiados en cuanto a distintos aspectos de su taxonomía e historia natural.

Si bien existen diferencias, por regla general, las características externas de los muroideos responden a un plan corporal generalizado (Carrizo et al. 2014; Maestri et al. 2016). Esta situación dificulta la identificación específica de especímenes sobre la base de rasgos externos fácilmente observables, práctica común en distintos trabajos en el campo. Al mismo tiempo, parte importante de la literatura que contiene datos morfológicos relevantes para la identificación de estos animales se encuentra dispersa y en publicaciones muchas veces antiguas y/o en la llamada literatura gris (e.g., Gyldenstolpe 1932; Yepes 1935a, 1935b; Massoia 1964, 1971, 1973a, 1973b, 1974, 1976, 1979; Massoia y Fornes 1964, 1965a, 1965b, 1967a, 1967b; Massoia et al. 1968), la que no siempre es de fácil acceso, al menos para cierto tipo de público (estudiantes, guardaparques, personal técnico de apoyo a la investigación, entre otros).

Independientemente de las dificultades que plantea la identificación de las especies de muroideos a partir de caracteres externos (sobre todo para quienes tienen poco entrenamiento) en la actualidad existe un número considerable de investigadores que de todos modos debe lidiar con esta problemática. En este contexto, la confección de una clave de identificación constituye una herramienta necesaria, y hasta ahora no disponible para los muroideos de Argentina, para el desarrollo de un conjunto importante de investigaciones en distintos campos de aplicación en nuestro país.

El objetivo de este trabajo es ofrecer una serie de claves para la identificación de los roedores muroideos de Argentina a partir de sus características externas. Una de 
las claves se centra en familias y subfamilias de Muroidea, otra en Sigmodontinae y la restante en Muridae. Se pretende que éstas sean una herramienta fácil de utilizar en el campo y el laboratorio, para que investigadores, personal técnico, o cualquier otro tipo de usuario no familiarizado con las especies del grupo, pueda determinar a nivel de especie ejemplares capturados en cualquier región geográfica de Argentina. Estas claves incluyen todas las especies de muroideos vivientes conocidas para Argentina, un conjunto que abarca 42 géneros y 110 especies (Teta et al. 2018, con modificaciones; e. g., Abreu et al. 2021; Prado et al. 2021; Teta et al. 2021).

\section{Materiales y métodos}

El formato de las claves sigue una estructura dicotómica, donde se han privilegiado las posibilidades de identificación antes que el ordenamiento taxonómico y las relaciones de parentesco entre las especies. Muchas especies de roedores muroideos son externamente muy similares entre sí, por lo cual es probable que el uso exitoso de la clave, al menos para los principiantes, demande de la ayuda de algunas herramientas adicionales (e. g., lecturas sobre terminología anatómica; Figuras 1 y 2) y cierta práctica o experiencia acumulada (e. g., en observación de animales en el campo y pieles de museos). A los fines de superar parcialmente esta situación, para cada taxón se incluye una enumeración de sus rasgos morfológicos diagnósticos y un párrafo con sus medidas externas, datos de distribución y hábitat. Además, intercaladas en las claves, se agregan una serie de notas taxonómicas, comparaciones entre especies similares y figuras, para que sirvan de ayuda en la identificación.

En la preparación de las claves sólo se han considerado caracteres externos, por ser los que pueden observarse más fácilmente en el campo. Para algunos géneros y especies seguramente no alcance sólo con esos datos, ya que una identificación inequívoca podría requerir del estudio de la anatomía craneana y dentaria, cariotipos o análisis de ADN (situación que se indica en cada caso). Los caracteres utilizados en las claves fueron tomados de la bibliografía (e. g., Gyldenstolpe 1932; Yepes 1935a; Pearson 1958; Massoia 1964, 1973a, 1973b, 1974, 1976, 1979; Massoia y Fornes 1964, 1965a, 1965b, 1967a, 1967b; Massoia et al. 1968; Myers 1989; Pearson 1995; Weksler et al. 2006; Bonvicino et al. 2008; Mares et al. 2008; Jayat et al. 2010; Teta et al. 2017) y contrastados, siempre que fue posible, con material de referencia, principalmente de la Colección Nacional de Mastozoología del Museo Argentino de Ciencias Naturales "Bernardino Rivadavia" (Ciudad Autónoma de Buenos Aires, Argentina) y la Colección de Mamíferos del Centro Nacional Patagónico (Puerto Madryn, Chubut). También hemos aprovechado nuestra experiencia de campo con las especies del grupo, utilizando información morfológica recopilada a lo largo de más de 20 años de trampeos.

La terminología anatómica corresponde a la discutida por Steppan (1995), Pacheco (2003), Weksler (2006) y Teta et al. (2017). En la construcción de las claves se privilegiaron los caracteres discretos y menos ambiguos (e. g., la longitud comparativa entre los dedos de las patas, el largo de las vibrisas, el tamaño y forma de las garras, la presencia de membranas interdigitales o de espinas, etc.), por sobre aquellos de valoración más subjetiva (e. g., la coloración del pelaje), siempre que fue posible. Cuando se considera, en la descripción de la coloración externa se ha privilegiado el aspecto general, sin entrar en detalles sobre la coloración de distintos tipos de pelos. La mayoría de los caracteres seleccionados pueden verse a ojo desnudo, aunque en algunos casos su correcta visualización pueda requerir de una lupa común (e. g., los surcos en la cara anterior de los incisivos). En algunos casos se hace referencia al efecto agutí, que está dado por pelos que incluyen bandas claras y oscuras alternadas (lo que les otorga a esos animales una apariencia como "salpicada"). Los caracteres que consideramos más relevantes para la identificación fueron resaltados en negrita; no obstante, en todas las especies se anotan varios caracteres adicionales que pretenden ayudar con las identificaciones.

Las claves están mayormente pensadas para la identificación de ejemplares adultos, con alguna mención a los juveniles cuando correspondiese. Hay que tener en cuenta que con cierta frecuencia los individuos jóvenes de distintos géneros (e. g., Akodon con Oxymycterus, Rattus con Sooretamys) o incluso los adultos (Abrothrix con Akodon) pueden prestarse a confusión, aún entre formas filogenéticamente distantes. En general, una coloración más oscura o grisácea, un pelaje más corto y fino y la proporción de algunas partes corporales (usualmente cabeza y patas grandes en relación con el tamaño del cuerpo) son rasgos típicos de los ejemplares que aún no han alcanzado la adultez.

Las medidas externas fueron tomadas de la literatura (e. g., Massoia 1964, 1974, 1976; Massoia y Fornes 1964, 1965a, 1965b; Massoia et al. 1968; Pardiñas et al. 2017) y de datos propios de los autores. En la mayoría de los casos se expresan como rango (mínimo y máximo), pero en unos pocos se indican valores medios. Todos los valores están expresados en milímetros. Para cada especie, se indican algunas de las siguientes medidas externas: LT = largo total, medido en línea recta vertebral desde el extremo del hocico hasta el extremo de la cola, sin incluir el pincel; $C C=$ longitud cabeza-cuerpo, medida en línea recta vertebral desde el extremo del hocico hasta la base de la cola (usualmente se obtiene restando la longitud de la cola del largo total [LT]); $C=$ longitud de la cola, medida desde su punto de inserción en el cuerpo hasta el extremo distal, sin incluir el pincel (si lo hubiese); $\mathrm{P}=$ longitud de la pata trasera, medida desde el borde posterior del talón hasta el extremo (incluyendo la uña) del dedo más largo; $\mathrm{O}=$ longitud de la oreja, medida desde la escotadura basal hasta el borde externo del pabellón auricular (Figura 1A). En forma orientativa, se han considerado 4 grupos de tamaño, según el largo CC: pequeño (hasta $100 \mathrm{~mm}$ ), mediano (entre 101 y $150 \mathrm{~mm}$ ), grande $(151-230 \mathrm{~mm})$ y muy grande $(>231 \mathrm{~mm})$. 
Para todas las especies se anotan datos de hábitat y una breve descripción de su distribución. Este punto no pretende ser exhaustivo y debe ser tomado con cautela, pues para muchas especies no hay información precisa sobre hábitat. La información distribucional también se utilizó para las claves en el caso de especies muy similares, pero con poblaciones geográficamente disyuntas (e. g., aquellas del género Bibimys). Mapas detallados de la distribución de todas las especies y fotografías adicionales se pueden consultar en https://cma.sarem.org.ar/. No obstante, téngase en cuenta que con frecuencia pueden producirse registros por fuera del área reconocida para una especie dada, ya que los límites de distribución no son estáticos, ni tenemos un conocimiento detallado de los mismos para todas las especies.

A modo de recomendación general, se sugiere que los usuarios de este trabajo lean y consideren todas las combinaciones de caracteres que se plantean en cada una de las entradas dobles antes de hacer una determinación y seguir avanzando en las claves.

\section{Resultados}

\section{Clave A. Familias y subfamilias}

1. Tamaño muy grande ( $C C=230-320 \mathrm{~mm} ; C=180-300$ $\mathrm{mm})$; patas traseras robustas y oscuras, con los dedos II-IV unidos por una membrana interdigital y garras bien desarrolladas de color blanco rosáceo; cola escamosa y desnuda, achatada lateralmente en toda su longitud, semejando un remo (humedales y cuerpos de agua en Tierra del Fuego)...............Cricetidae, Arvicolinae (introducida, un solo género y especie, Ondatra zibethicus; Figura 22A)

1a. Tamaño pequeño a grande, la longitud CC $<230 \mathrm{~mm}$; cola de sección redondeada a ovalada y generalmente menor que $200 \mathrm{~mm}$ 2

2. Cola con escamado dérmico visible o no, escasamente a densamente cubierta de pelos; generalmente en áreas naturales..................Cricetidae, subfamilia Sigmodontinae (clave B; Figuras 1-21)

2a. Cola mayormente desnuda, con escamado dérmico bien visible; generalmente de hábitos peridomiciliarios. familia Muridae (clave C. Figura 22B-D)

\section{Clave B. Subfamilia Sigmodontinae}

1. Tamaño mediano ( $C C=105-120 ; C=112-133 ; P=28-29$; $\mathrm{O}=17$ ); pelos del dorso y flancos modificados en forma de espinas achatadas ( 11 $\mathrm{mm}$ de longitud), transparentes o blanquecinas en su porción proximal y distalmente marrones; cabeza robusta; orejas medianas y redondeadas; coloración dorsal marrón grisácea, con marcado efecto agutí; cola marrón oscuro, más larga que la longitud conjunta de la cabeza más el cuerpo y terminada en un pincel de pelos marrón oscuro; manos con los dos dedos centrales muy alargados (Figura 2A); patas traseras alargadas $y$ dorsalmente cubiertas por
A LT
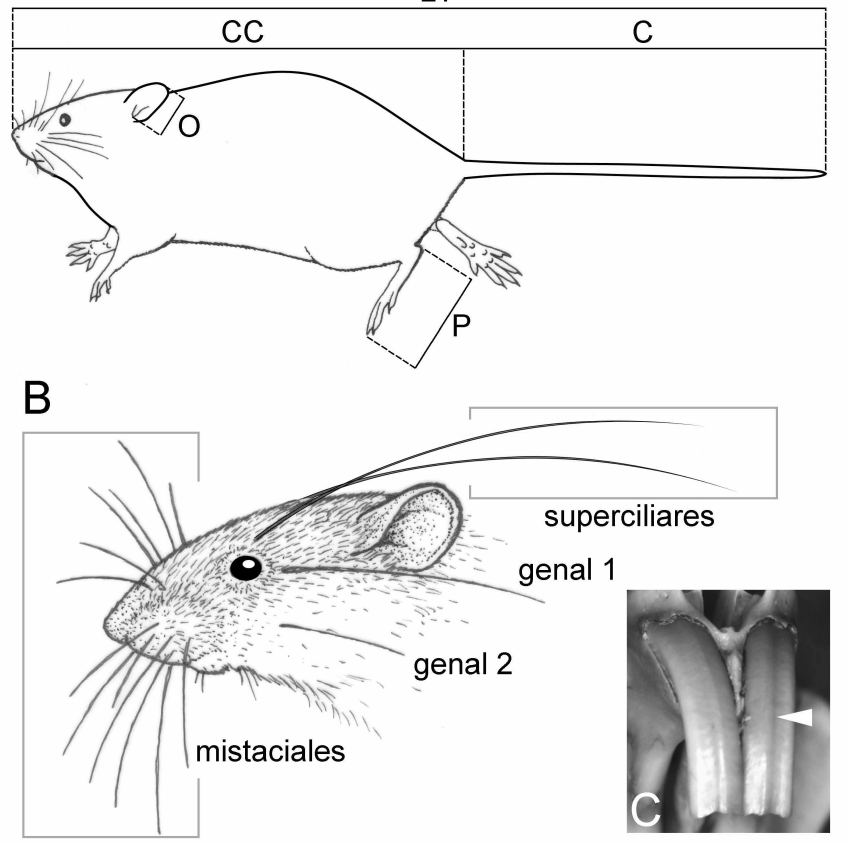

Figura 1. A) Medidas somáticas estándar para mamíferos: CC, largo cabeza-cuerpo; $\mathrm{C}$, largo de la cola; LT, largo total; $\mathrm{O}$, largo de la oreja; $\mathrm{P}$, largo de la pata trasera. B) vibrisas faciales (sólo se anotan las mencionadas en el texto). C) cara anterior de los incisivos en Euneomys mordax (la flecha muestra la posición del surco longitudinal).

pelitos oscuros (Figura 2B) (selvas primarias y secundarias en Misiones)..............Abrawayaomys ruschii (Figura 3A)

1a. Sin pelos modificados en forma de espinas........................2

2. Los dedos de las patas traseras están unidos por una membrana cutánea..

2a. Los dedos de las patas traseras no están unidos por una membranacutánea.

3. Tamaño grande $(C C=165-258 ; C=151-287 ; P=47-59 ; O$ = 23-25); cuerpo rollizo; cola gruesa y escamosa, igual de larga que la longitud cabeza-cuerpo; pelaje fino y suave, dorsalmente castaño oscuro brillante, con pelos negros más largos entremezclados; flancos lavados de amarillento; vientre blanquecino a grisáceo, lavado de ocre; cabeza grande, con ojos y orejas medianos; vibrisas mistaciales (Figura 1B) oscuras y brillantes, las más largas alcanzan la mitad de la oreja; patas alargadas, dorsalmente cubiertas por pelitos blancos; borde del pie cubierto por un peine de pelos blancos; plantas amplias, desnudas y escamadas hasta el talón; almohadilla hipotenar pequeña; la membrana cutánea de los dedos II-IV de la pata posterior se extiende por delante de la segunda articulación interfalangeana (Figura 2G-H) (cursos de agua en selvas de Misiones) ....... ...Nectomys squamipes (Figura 3E)

3a. La membrana cutánea en los dedos II-IV se extiende hasta la primera articulación interfalangeana o menos (Figura 2E-F). . .4

4. Tamaño mediano ( $C C=99-127 ; C=102-133 ; P=27-31 ; O$ =13-19); cola igual de larga que la longitud conjunta de la cabeza más el cuerpo; pelaje largo y suave; colo- 

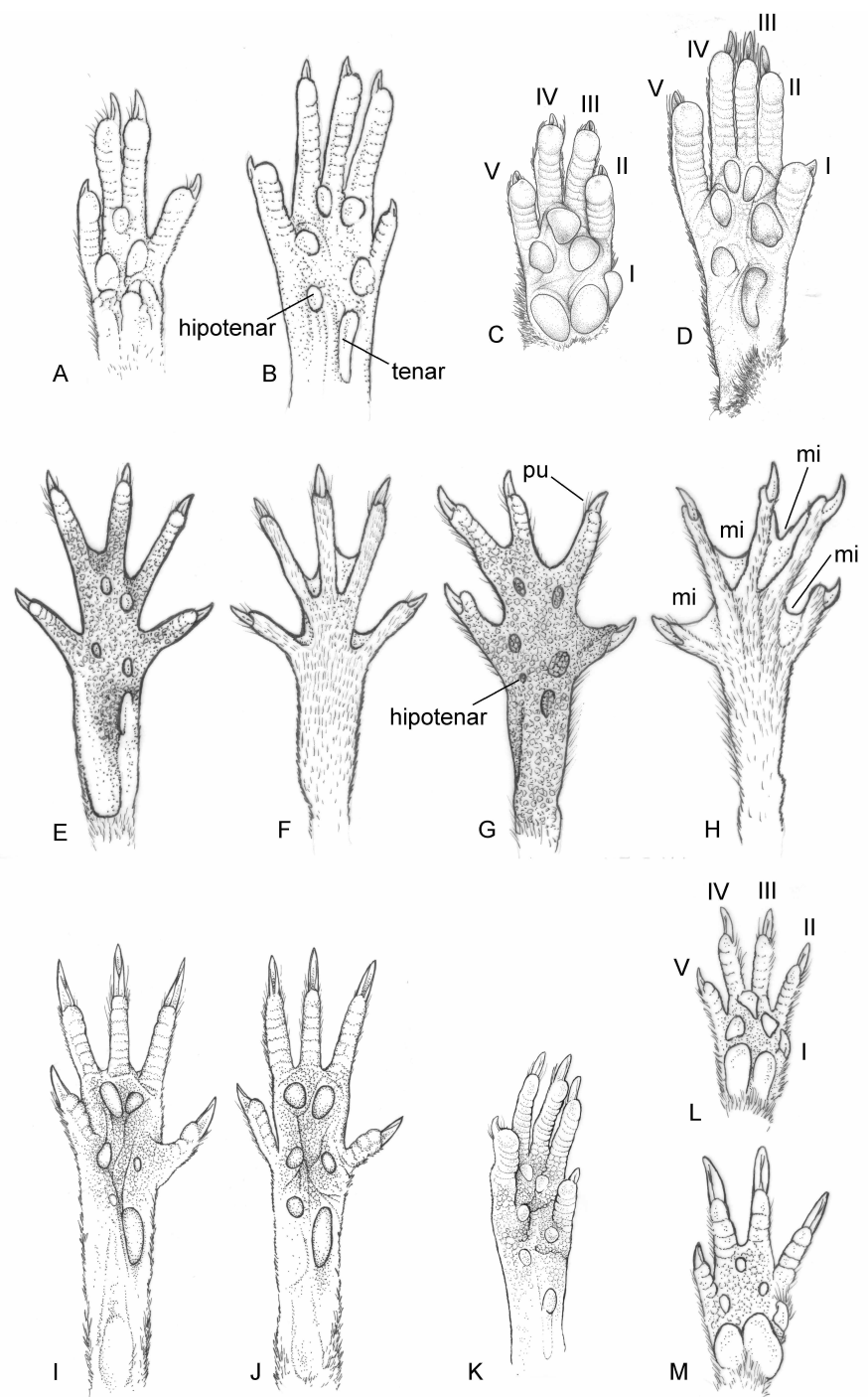

Figura 2. Esquemas de las manos en vista palmar $(A, C, L, M)$ y patas en vista dorsal $(\mathrm{F}, \mathrm{H})$ y plantar $(\mathrm{B}, \mathrm{D}, \mathrm{E}, \mathrm{G}, \mathrm{I}, \mathrm{J}, \mathrm{K})$ de Abrawayaomys ruschi $(\mathrm{A}, \mathrm{B})$, Juliomys pictipes $(\mathrm{C}, \mathrm{D})$, Holochilus brasiliensis (E, F), Nectomys squamipes (G, H), Gyldenstolpia fronto (I), Scapteromys aquaticus (J), Oligoryzomys nigripes (K), Brucepattersonius iheringi $(\mathrm{L})$ y Oxymycterus rufus (M) (redibujados de varias fuentes). Los números romanos corresponden a los que identifican a cada dedo. Abreviaturas: mi, membrana interdigital; pu, pelos ungueales. Las figuras no están en escala.

ración dorsal marrón olivácea, con efecto agutí, más clara hacia los flancos; vientre blanco amarillento, poco contrastado con el color del dorso; orejas medianas; patas posteriores estrechas, cubiertas por pelitos blanco-grisáceos por arriba y con los dedos II-IV reunidos en sus bases por una membrana cutánea rudimentaria; pelos ungueales blancos y cortos, raramente extendidos por delante de las uñas; cola bicolor, oscura por arriba y más clara por debajo, con las escamas visibles; 4 pares de mamas (pastizales, palmares y humedales, desde el este de Formosa hasta el norte de Santa Fe).........

Pseudoryzomys simplex (Figura 3B)

4a. Tamaño grande; cuerpo rollizo con cola mediana a larga, gruesa, fuerte y escamosa; cabeza grande, con hocico obtuso (romo o que no termina en punta); ojos y orejas medianos; vibrisas cortas y poco abundantes, que no alcanzan la base de la oreja; pelaje dorsal con tonos rojizos o castaños, más oscuro hacia la línea media y anaranjado hacia los flancos; manos y patas muy desarrollados, dorsalmente cubiertos por pelitos blancos; dedos de las patas traseras reunidos por una membrana cutánea rudimentaria; pelos ungueales cortos y escasos; palmas y plantas desnudas, con escamación entre las almohadillas interdigitales y la tenar; almohadilla hipotenar ausente o muy reducida (Figura 2E-F); 4 o 5 pares de mamas. Holochilus (Figura 3C-D) 5

5. Tamaño grande $(C C=185-238 ; C=200-238 ; P=47-55$; $\mathrm{O}=21-26) ;$ pelaje largo, denso y suave; coloración dorsal castaño anaranjada a rojiza, con pelos más largos de color negro entremezclados; vientre de color blanco puro, a veces con una faja transversal ocre-anaranjada, castaña o grisácea y con parches blancos en el mentón y el área inguinal; longitud de la cola mayor que la longitud CC (humedales y cursos de agua en el noreste y centro-este de Argentina, hasta el sur de Buenos Aires) Holochilus brasiliensis (Figura 3D)

5a. Longitud de la cola menor que la longitud CC. .6

6. Tamaño grande $(C C=140-195 ; C=148-183 ; P=38-46 ; O$ = 17-20); coloración dorsal castaño anaranjada a rojiza, con pelos más largos de color negro entremezclados; pelaje ventral blanco puro o blanco grisáceo u ocráceo, pero con el mentón y región inguinal siempre de color blanco puro (humedales y cursos de agua desde Salta y Jujuy hasta Santa Fe y el norte de Buenos Aires)... Holochilus chacarius (Figura 3C)

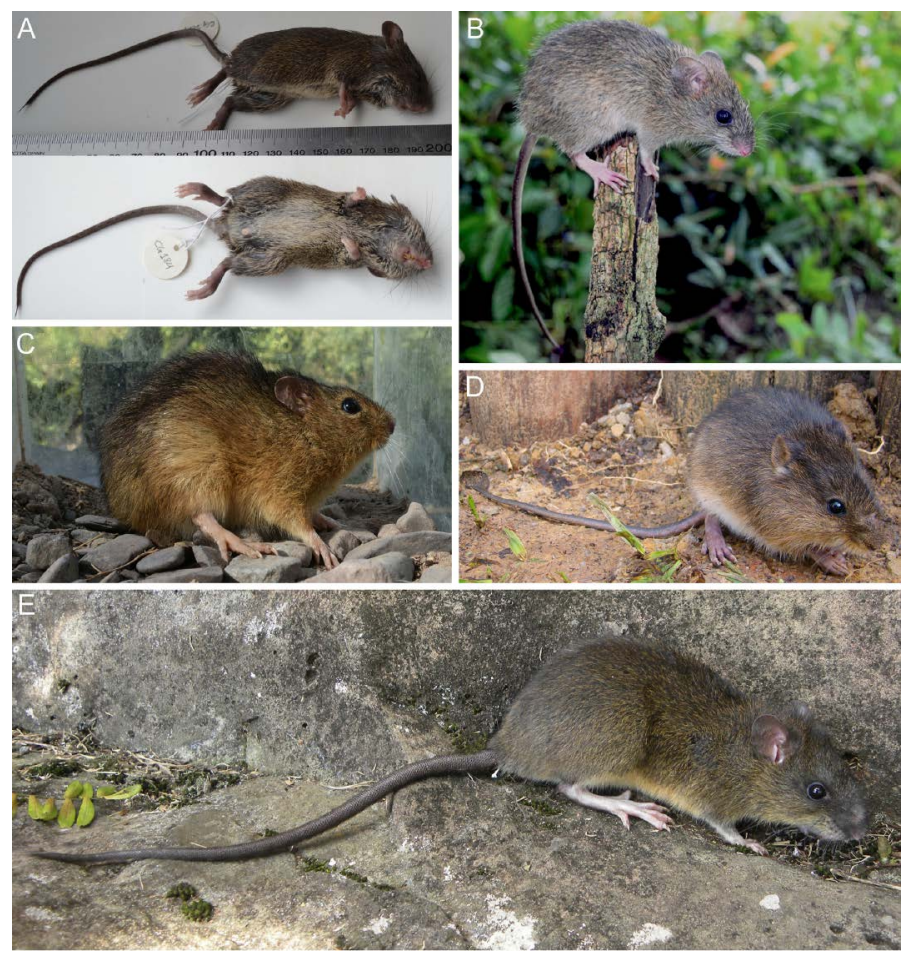

Figura 3. Aspecto externo de Abrawayaomys ruschi (A), Pseudoryzomys simplex (B), Holochilus chacarius (C), Holochilus brasiliensis (D) y Nectomys squamipes (E). Las fotos no están en escala. 
6a. Tamaño grande ( $C C=$ no disponible; $C \sim 136 ; P=46 ; 0$ = no disponible); coloración dorsal rojiza, más oscura en la línea media y anaranjada hacia los flancos; vientre grisáceo, con una banda pectoral anaranjada entre las patas delanteras y parches de pelos completamente blancos en el mentón, garganta y el área inguinal (humedales y cursos de agua en Mendoza; posiblemente extinta) Holochilus lagigliai

7. Cara anterior de los incisivos superiores con un surco longitudinal, de posición medial o lateral, visible a ojo desnudo o mediante lupa (Figura 1C).

.. .8

7a. Cara anterior de los incisivos superiores sin surco longitudinal. . .15

8. Tamaño mediano ( $C C=108-130 ; C=162-196 ; P=28-32$; $\mathrm{O}=17$ ); pelaje fino y suave, de color marrón acanelado o marrón grisáceo en el dorso y blanco-grisáceo, a veces lavado de canela, en el vientre; orejas medianas y muy oscuras, a veces con un parche de pelos blancos en la base; ojos grandes, rodeados por un anillo de pelos oscuros; patas traseras alargadas y dorsalmente cubiertas por pelitos blancos; cola moderadamente gruesa y mucho más larga que la longitud conjunta de la cabeza más el cuerpo, negruzca dorsalmente y apenas más clara por debajo (bosques y matorrales ecotonales, desde el oeste de Neuquén hasta el sudoeste de Chubut) Irenomys tarsalis (Figura 4A)

8a. Cola menor que el $65 \%$ de la longitud conjunta de la cabeza más el cuerpo

9

9. Con aspecto general de conejo; cuerpo robusto y rechoncho; cabeza grande, con el perfil dorsal convexo; ojos redondos y grandes; orejas redondeadas y prominentes; pelaje largo, denso y suave, con parches de pelos más claros en la base de las orejas y alrededor de los ojos; miembros anteriores cortos y posteriores más largos; manos y patas cubiertas por pelitos blancos; dedos provistos de garras cortas; el extremo distal de los dedos I y $\mathrm{V}$ en las patas traseras no alcanza la base de los dedos III-IV; cola bicolor y moderadamente peluda; 4 pares de mamas. Reithrodon 10

9a. Sin aspecto general de conejo; orejas medianas o grandes; sin parche de pelos claros en la base de las orejas; el extremo distal del dedo $\mathrm{V}$ de la pata trasera sobrepasa la base del IV.. . .12

10. Tamaño mediano ( $C C=128-160 ; C=65-100 ; P=30-34$; $\mathrm{O}=23-25$ ); coloración dorsal variable, desde marrón hasta gris, más oscura en la línea media y lavada de amarillento hacia los flancos; vientre blanquecino a grisáceo, usualmente lavado de amarillento o canela; plantas de las patas mayormente cubiertas por pelos, dedos con pelos ungueales largos y abundantes (pastizales y estepas arbustivas y herbáceas desde Buenos Aires, La Pampa y sudoeste de Mendoza hasta Tierra del Fuego; también en pastizales de altura en Córdoba). Reithrodon auritus (Figura 4D) 10a. Tamaño mediano; plantas de las patas mayormente desnudas, dedos con pelos ungueales largos pero poco abundantes. ...11

11. Tamaño mediano ( $C C=127-149 ; C=94-99 ; P=30.5$ 34.5; $\mathrm{O}=24-28$ ); coloración dorsal castaño-ocrácea, más oscura hacia la línea media y la parte superior de la cabeza y amarillenta hacia los flancos; vientre blanquecino, sin lavado amarillento o castaño (pastizales de altura por encima de los 2,000 msnm en Catamarca, Jujuy y Tucumán). Reithrodon caurinus

11a. Tamaño mediano ( $C C=139-152 ; C=90-94 ; P=27-31$; $\mathrm{O}=22-27)$; coloración dorsal castaño clara a marrón, más oscura hacia la línea media y la parte superior de la cabeza y amarillenta hacia los flancos; vientre blanquecino a grisáceo, lavado de amarillento. (pastizales en Corrientes y Entre Ríos). Reithrodon typicus

12. Tamaño mediano ( $C C=98-125 ; C=52-69 ; P=21-25$; $0=20-24)$; pelaje largo, laxo y suave; coloración dorsal grisácea, lavada de amarillento en el dorso y de anaranjado hacia los flancos y grupa; vientre grisáceo teñido de ocre, bien separado del dorso; orejas grandes y de contorno ovalado; parche postauricular de pelos ocres; mejillas gris ocráceas; vibrisas largas, pero que no sobrepasan el borde externo de la oreja; orejas marrón oscuro, cubiertas por pelitos dispersos anaranjados; cola blanco grisácea, excepto por una fina línea dorsal oscura; incisivos superiores blancos 0 amarillo pálidos, con un surco poco profundo y visible bajo lupa; patas robustas, dorsalmente cubiertas por pelitos blanco grisáceos; palmas y plantas desnudas; pelos ungueales largos, que cubren parcialmente las uñas; cola blanco grisácea, excepto por una fina línea dorsal oscura, proporcionalmente muy corta, algo gruesa y peluda (pastizales, matorrales y roquedales de la Puna y Altos Andes, por encima de 3,200 msnm en Jujuy y Salta).................................. Auliscomys sublimis (Figura 5B)

12a. Sin parche postauricular; orejas medianas y de contorno casi circular; incisivos anaranjados.

13. Tamaño grande ( $C C=160-180 ; C=60-85 ; P=23-25$; $\mathrm{O}=18-19$ ); cuerpo robusto y miembros cortos; hocico castaño rojizo brillante; pelaje largo y espeso, dorso marrón grisáceo; vientre blanco grisáceo; faja pectoral de pelos ocres variablemente presente; cabeza grande, con vibrisas abundantes y orejas medianas, redondeadas y bien cubiertas de pelos; grupa teñida de castaño rojizo; manos y patas cubiertos por pelitos grises a ocres; palmas y plantas desnudas; cola peluda y bicolor; incisivos superiores anchos, con un surco longitudinal de posición lateral; 4 pares de mamas (pastizales húmedos asociados a vegas y cursos de agua por encima de los 2,600 msnm, desde Jujuy hasta el norte de San Juan) .... Neotomys ebriosus (Figura 4E)

13a. Hocico y grupa sin castaño rojizo; cuerpo robusto y miembros cortos; pelaje suave y denso; cabeza grande, con orejas redondas y medianas; vibrisas largas, algu- 
nas claras y otras oscuras, alcanzando posteriormente el pabellón auditivo; sin faja pectoral; palmas y plantas desnudas, cubiertas por almohadillas amplias; 4 pares de mamas (desde el sur de San Juan hasta Tierra del Fuego) Euneomys (Figura 4B-C) 14

14. Tamaño mediano $(C C=97-156 ; C=46-81 ; P=22-32 ; O=$ 19-24); coloración dorsal marrón, lavada de amarillento o gris, más oscura hacia la línea media; vientre blanco-grisáceo, a veces lavado de amarillento; cola bicolor, con la mitad dorsal oscura y formando una banda ancha todo a lo largo; manos, pies, borde del hocico y labios blancos; cara anterior de los incisivos con un surco longitudinal, de posición lateral (roquedales y peladares desde el sur de San Juan hasta Tierra del Fuego)...........

...Eneomys chinchilloides (Figura 4B)

14a. Tamaño mediano ( $C C=145-149 ; C=78-85 ; P=28-32$; $\mathrm{O}=24-27)$; coloración dorsal marrón grisácea, más clara hacia los flancos y el vientre, que es gris; cola bicolor, con la mitad dorsal oscura y formando una banda fina todo a lo largo; sin blanco en hocico y labios; cara anterior de los incisivos con un surco longitudinal, de posición central (pastizales húmedos, praderas herbáceas de altura y matorrales en el sudoeste de Mendoza y oeste de Neuquén, por encima de los 1600 msnm)..

..Euneomys fossor (Figura 4C)
15. Tamaño pequeño $(C C<100 \mathrm{~mm})$; cola aproximadamente igual o levemente más larga que la longitud conjunta de la cabeza más el cuerpo; cabeza proporcionalmente grande, con rostro corto y perfil abovedado; pelaje largo, sedoso y suave, usualmente marrón amarillento, que contrasta con el vientre blanco; orejas medianas, cubiertas por pelos cortos amarillentos a marrones; área alrededor de la nariz y boca cubierta por pelos blancos; miembros anteriores cortos y posteriores bien desarrollados; manos y patas cubiertos dorsalmente por pelos blanquecinos; plantas de las patas con las tres almohadillas interdigitales centrales fusionadas en un tubérculo único, cubierto de pelos; hipotenar ausente; dedo $\mathrm{V}$ del pie largo, con el extremo (sin la garra) alcanzando o sobrepasando el extremo distal de la primer falange del dedo IV; almohadillas palmares variablemente fusionadas e igualmente peludas (Figura 6D); 4 pares de mamas (estepas arbustivas y herbáceas en áreas abiertas, normalmente asociadas con ambientes de suelo predominantemente arenoso) ...Eligmodontia (Figura 6A-D) 16

Nota 1: la identificación de las especies del género Eligmodontia es difícil de realizar sólo sobre la base de caracteres externos, requiriendo usualmente de estudios de morfología cráneo-dentaria, cariotípicos y de ADN.
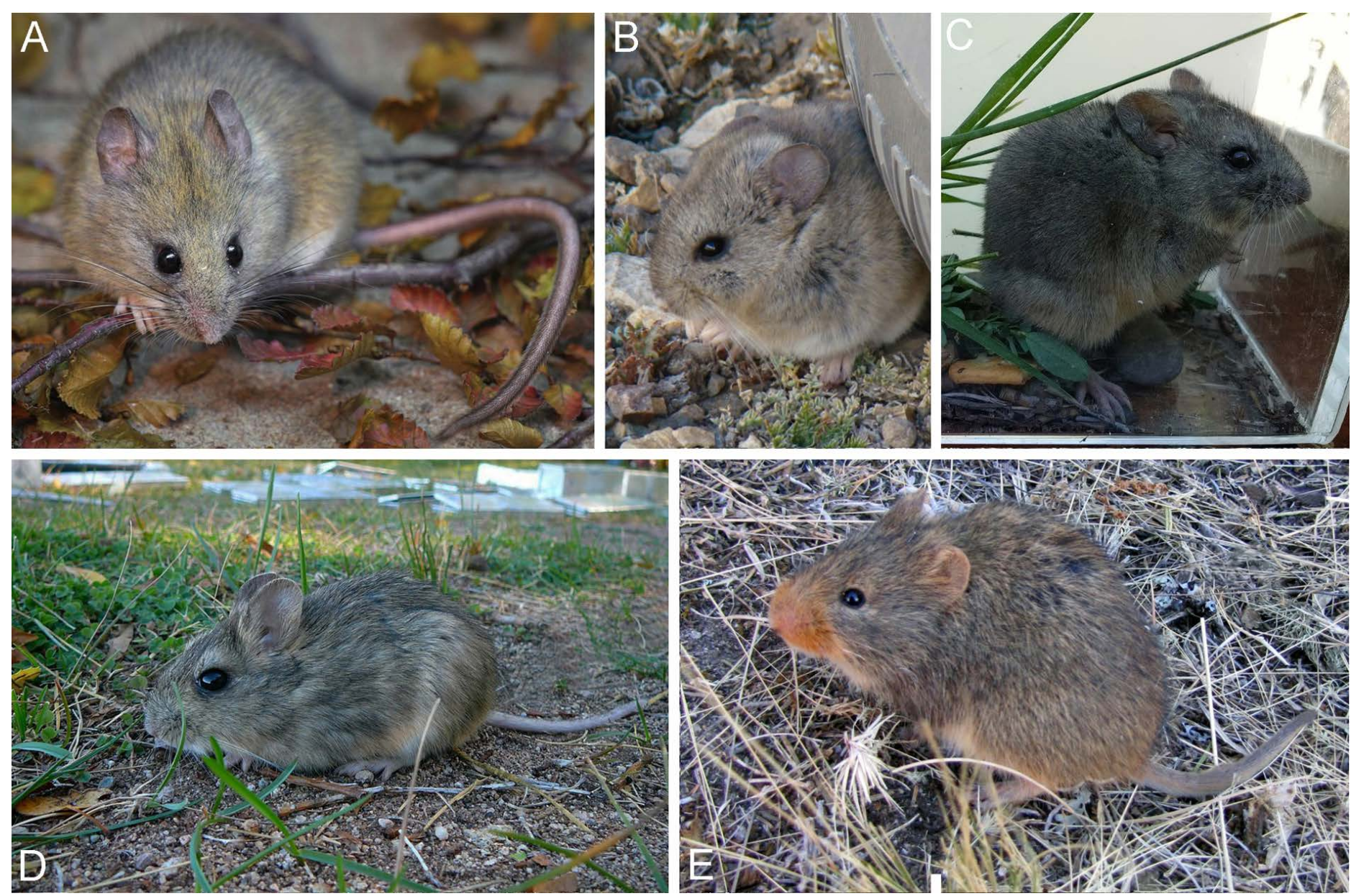

Figura 4. Aspecto externo de Irenomys tarsalis (A), Euneomys chinchilloides (B), Euneomys fossor (C), Reithrodon auritus (D) y Neotomys ebriosus (E). Las fotos no están en escala. 


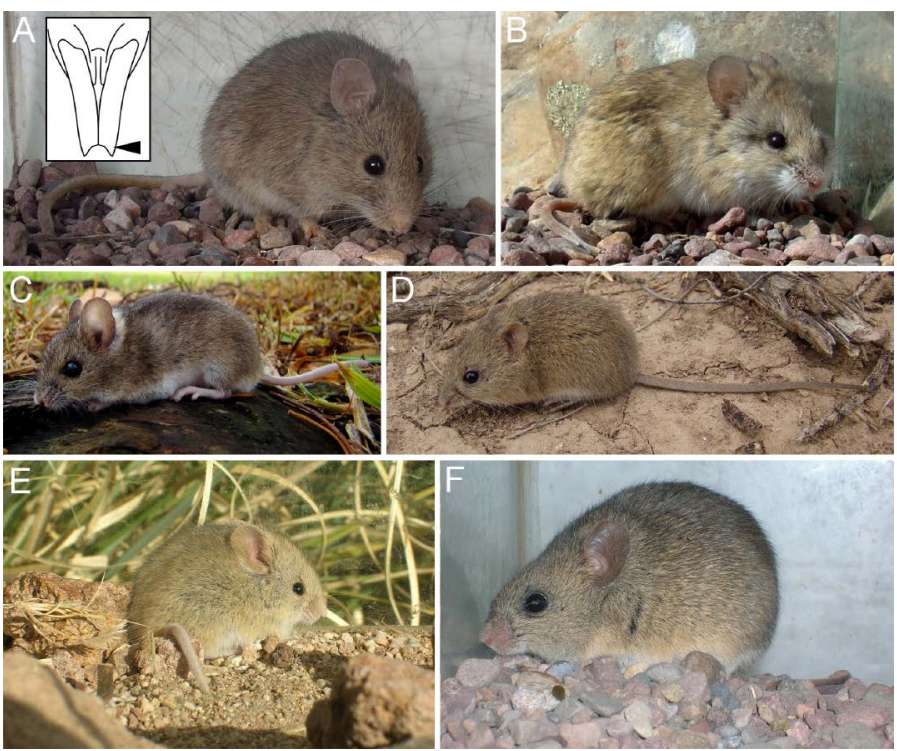

Figura 5. Aspecto externo de Andinomys edax ( $\mathrm{A}$; en el recuadro interno se ilustra la cara anterior de los incisivos; la flecha destaca el borde biselado de estos dientes en su extremo distal), Auliscomys sublimis (B), Calomys laucha (C), Calomys musculinus (D), Calomys lepidus (E) y Calomys fecundus (F). Las fotos no están en escala.

15a. Almohadillas interdigitales no fusionadas.

16. Plantas de las patas densamente peludas; largo de la cola $\sim 90-93 \%$ de la longitud conjunta de la cabeza más el cuerpo.

16a. Plantas de las patas escasamente peludas; largo de la cola $\sim 110-130 \%$ de la longitud conjunta de la cabeza más el cuerpo.

17. Tamaño pequeño $(C C=75-100 ; C=69-90 ; P=21-25$; $\mathrm{O}=14-19)$; coloración dorsal marrón claro, lavada de dorado en los flancos; vientre y pecho blancos, que contrastan notoriamente con el color del dorso (estepas arbustivas en el sudoeste de Mendoza y la Patagonia)............................Eligmodonta morgani (Figura 6B y D)

17' Tamaño pequeño $(C C=65-105 ; C=67-97 ; P=21-25$; $\mathrm{O}=15-22)$; coloración dorsal marrón grisáceo a marrón claro, bien separada del vientre por una línea anaranjada que se extiende desde las mejillas hasta las ancas; cola levemente bicolor a unicolor, sin pincel de pelos (estepas arbustivas altoandinas y de la puna de Jujuy, Salta y Catamarca, por encima de los 3,500 msnm) ...... Eligmodontia puerulus

18. Tamaño pequeño $(C C=60-90 ; C=84-106 ; P=19-23 ; O$ = 16-20); dorso marrón amarillento, separado del vientre por una línea ocrácea; vientre blanco, con la base de los pelos generalmente gris; cola bicolor (estepas arbustivas y medanales desde el sur de Catamarca hasta el noreste de Santa Cruz)

Eligmodontia typus (Figura 6C)

18a. Vientre blanco puro, base de los pelos completamente blanca.

19. Tamaño pequeño $(C C=73-94 ; C=74-105 ; P=21-26 ; O$ = 15-19); dorso marrón amarillento pálido; cola completamente blanquecina, sin pincel de pelos conspicuo (estepas arbustivas en el sur de Salta y este de Catamarca)

Eligmodontia bolsonensis (Figura 6A)

19a. Tamaño pequeño $(C C=80-99 ; C=99-121 ; P=23-26 ; O$ = 18-26); cola bicolor y terminada en un pincel de pelos ( $\sim 5 \mathrm{~mm})$. Similar a E. bolsonensis, pero más grande y con el dorso menos amarillento, el área alrededor de los ojos más pálida y las orejas más oscuras (estepas arbustivas; desde Catamarca, por el oeste, hasta el sur de Mendoza) Eligmodontia moreni

20. Longitud de la cola igual o más larga que la longitud conjunta de la cabeza más el cuerpo; vibrisas mistaciales medianas a largas, que extendidas hacia atrás sobre las mejillas suelen sobrepasar el borde externo de la oreja...

20a. Longitud de la cola más corta que la longitud conjunta de la cabeza más el cuerpo; vibrisas mistaciales cortas a medianas, que extendidas hacia atrás sobre las mejillas no suelen sobrepasar el borde externo de la oreja........47

Nota 2: en Andinomys edax la longitud de la cola varía entre el 75 (más corta) y 95\% (casi igual) de la longitud combinada de la cabeza más el cuerpo. Si se llega a este punto de la clave, conviene repasar los rasgos que definen a esa especie, los cuales se anotan en la entrada 61.

21. Tamaño mediano ( $C C=117-135 ; C=100-145 ; P=27-32$; $\mathrm{O}=16-20)$; cuerpo alargado; coloración dorsal gris amarronada, más oscura hacia la línea media, con o sin una línea negra longitudinal marcada desde la nuca hasta la base de la cola; vientre grisáceo, bien contrastado con el dorso; hocico agudo y orejas largas, mayormente desnudas y redondeadas; pelaje dorsal corto y espeso;
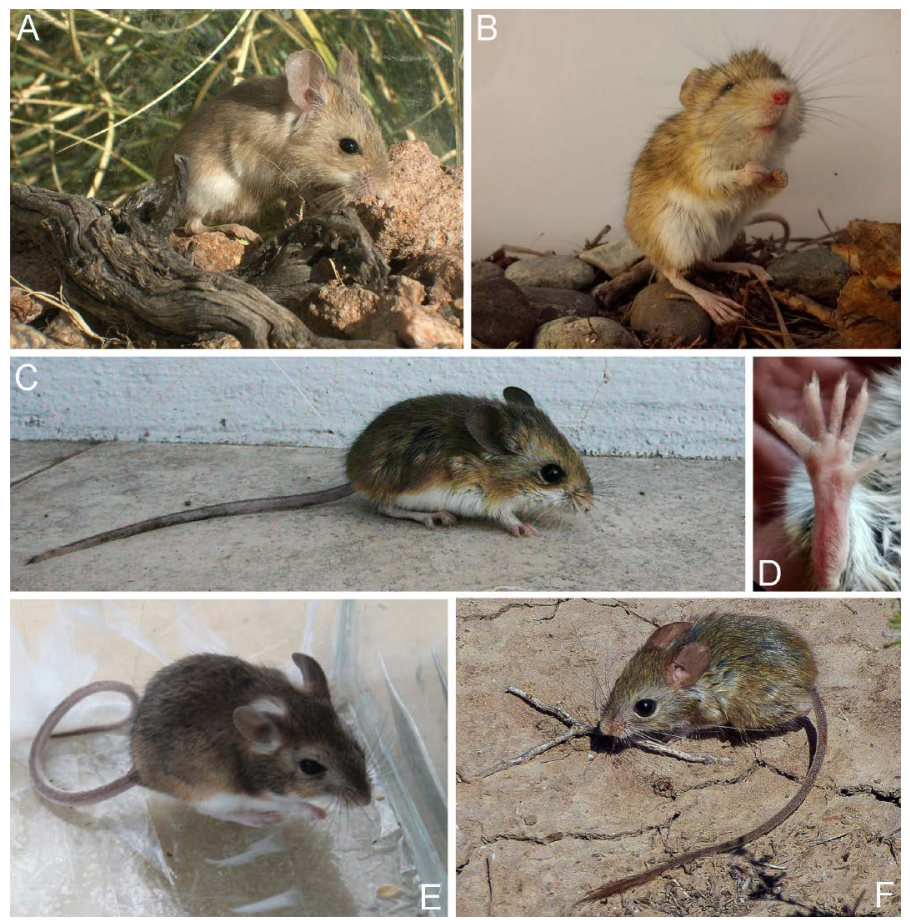

Figura 6. Aspecto externo de Eligmodontia bolsonensis (A), Eligmodontia morgani (B y D; en D se muestra un detalle de la superficie plantar de la pata trasera, en donde se destacan las almohadillas interdigitales centrales fusionadas), Eligmodontia typus (C), Andalgalomys olrogi (E) y Salinomys delicatus (F). Las fotos no están en escala. 
patas angostas, con la garra del dedo I extendida hasta la mitad de la falange del dedo II y la garra del dedo $\mathrm{V}$ hasta ca. la segunda articulación interfalangeana del dedo IV; plantas desnudas, con almohadillas grandes y carnosas, y escamación evidente sólo en la parte distal del metatarso; pelos ungueales blanco plateados, que cubren parcialmente las uñas; cola bicolor, con escamado dérmico evidente y aproximadamente igual de larga que la longitud conjunta de la cabeza más el cuerpo; 3 o 4 pares de mamas (selvas en Misiones) ..........

Delomys dorsalis (Figura 7A)

21a. Combinación de caracteres no como en la opción anterior.

22. Tamaño pequeño $(C C=85-110 ; C=82-97 ; P=19-21$; $\mathrm{O}=12-15)$; coloración general castaño rojiza, más brillante y anaranjada en el hocico, grupa, y muslos; vientre blanco-amarillento, bien separado del dorso y lavado de naranja en la región inguinal y la base de la cola; orejas pequeñas y cubiertas dorsalmente por pelos marrones; vibrisas largas, con algunas que sobrepasan el borde posterior de las orejas; patas cortas, pero anchas, dorsalmente cubiertas por pelitos anaranjados, con almohadillas plantares prominentes; almohadilla hipotenar en forma de coma, con el borde anterior en la misma línea que el borde posterior de la tenar (Figura 2C-D); dedos blancos, con pelos ungueales abundantes y más largos que las uñas; cola bicolor, excepto por la porción terminal que es oscura todo alrededor y aproximadamente igual de larga que la longitud conjunta de la cabeza más el cuerpo; 4 pares de mamas (selvas en Misiones) Juliomys pictipes (Figura 7B)

Nota 3: Juliomys puede confundirse con Oligoryzomys spp., pero se diferencia por tener la cabeza y los ojos proporcionalmente más grandes, las patas más anchas y la cola más corta.

22a. Combinación de caracteres no como en la opción anterior. 23

23. Longitud CC usualmente menor que $120 \mathrm{~mm}$.

23a. Longitud CC usualmente mayor que $120 \mathrm{~mm}$ 31

Nota 4: la separación entre un grupo de especies con longitudes de CC mayores o menores de $120 \mathrm{~mm}$ es orientativa; frente a esta disyuntiva, lo más conveniente es que el usuario de la clave evalúe alternativamente las distintas opciones posibles.

24. Sin manchas blancas alrededor de la nariz y la boca; pelaje fino y suave, dorsalmente castaño rojizo a castaño amarillento; flancos y mejillas más claros, a veces con tonalidades anaranjadas formando una línea; límite entre dorso y vientre moderadamente a bien definido; vientre blanco grisáceo o amarillento, con pelos individuales de base gris; ojos grandes; orejas medianas y redondeadas; vibrisas largas, que extendidas hacia atrás sobre las mejillas alcanzan o sobrepasan el borde externo de las orejas; patas largas y finas, con dedos largos (especialmente el primero), cubiertas por pelitos

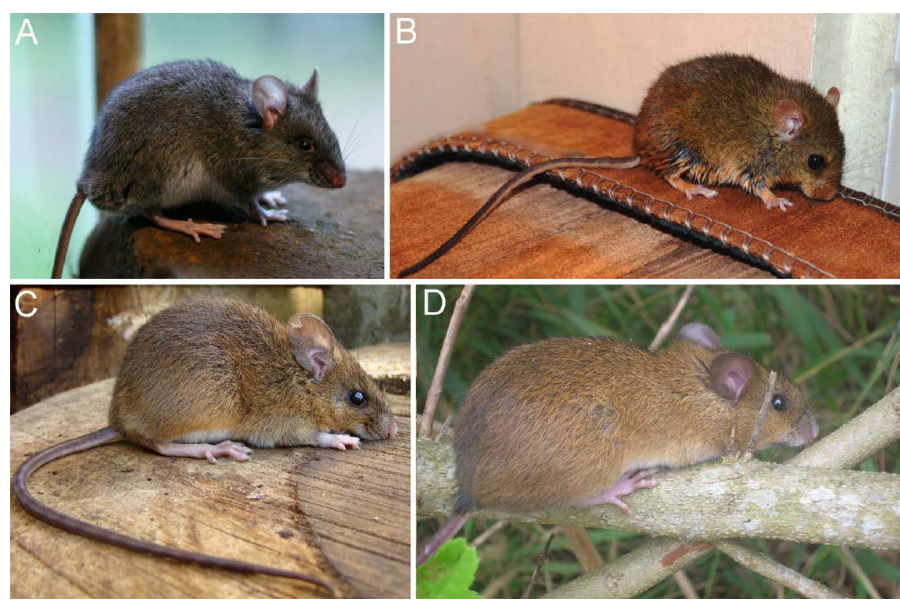

Figura 7. Aspecto externo de Delomys dorsalis (A), Juliomys pictipes (B), Euryoryzomys russatus (C) y Euryoryzomys legatus (D). Las fotos no están en escala.

claros (Figura 2K); cola fina, bicolor, poco peluda y comparativamente larga; 4 pares de mamas.

.Oligoryzomys (Figura 8A-E) 25

Nota 5: la identificación de las especies del género Oligoryzomys es difícil de realizar sólo sobre la base de caracteres externos, requiriendo usualmente de estudios de morfología cráneo-dentaria, cariotípicos y de ADN.

24a. Con manchas blancas alrededor de la nariz y la boca y parches post y subauriculares del mismo color; pelos del vientre de color blanco puro.

29

25. Tamaño pequeño a mediano ( $C C=80-110 ; C=101-146$; $\mathrm{P}=18-30 ; \mathrm{O}=13-19$ ); dorso marrón anaranjado (parecido al color de un ladrillo), con línea lateral indistinta o apenas anaranjada; vientre blanquecino contrastado fuertemente con el dorso, lavado de amarillento en algunos casos, pero siempre con mentón y garganta completamente blancos; orejas cubiertas por pelitos anaranjados, con un parche de pelos anaranjados por delante; cola moderadamente bicolor (pastizales, pajonales, matorrales del Chaco y bosques de transición con las Yungas, desde Formosa, Jujuy y Salta hasta el norte de Santiago del Estero, casi siempre por debajo de los 900 msnm).................. Oligoryzomys chacoensis (Figura 8A)

Nota 6: O. chacoensis se diferencia de $O$. flavescens-O. fornesi por su mayor tamaño y vientre más blanco, y de O. nigripes por su coloración más pálida y amarillenta, ausencia de faja pectoral y vientre más blanco.

25a. Coloración, medidas y/o distribución no como en la opción anterior.. .26

26. Tamaño pequeño a mediano ( $C C=83-105 ; C=108-135$; $\mathrm{P}=26-29 ; \mathrm{O}=15-18$ ); pelaje más largo, suave y oscuro que en otras especies del género; dorsalmente marrón, lavado de amarillo o anaranjado hacia los flancos; vientre blanco grisáceo; orejas cubiertas por pelitos ocres; patas dorsalmente blanquecinas (pastizales, pajonales, matorrales y áreas forestadas en el Monte y la Patagonia, desde el sur de Buenos Aires, La Pampa y 
Mendoza hasta Tierra del Fuego) ... Oligoryzomys longicaudatus (Figura 8C)

26a. Coloración, medidas y/o distribución no como en la opción anterior.

27. Tamaño pequeño a mediano ( $C C=70-130 ; C=96-155 ; P$ = 21-29; $\mathrm{O}=14-20)$; dorso marrón anaranjado a marrón grisáceo, con el vientre blanco grisáceo a gris claro (nunca ocráceo); faja pectoral anaranjada usualmente presente, extendiéndose entre las patas delanteras; cola bicolor; orejas cubiertas por pelitos grises (selvas y matorrales desde Misiones y Formosa hasta el nordeste de Buenos Aires)

Oligoryzomys nigripes (Figura 8B)

Nota 7: O. nigripes se diferencia de $O$. flavescens-O. fornesi por su mayor tamaño y el color más oscuro de sus orejas.

27a. Coloración, medidas y/o distribución no como en la opción anterior. 28

28. Tamaño pequeño ( $C C=69-109 ; C=94-155 ; P=22-29$; $\mathrm{O}=14-20)$; dorso castaño anaranjado, más grisáceo hacia la cabeza y lavado de amarillento hacia los flancos; vientre blanco grisáceo a gris amarillento o anaranjado; orejas oscuras, cubiertas por pelitos marrones (áreas forestadas, principalmente de las Yungas, pero también en algunas zonas del Chaco Serrano, pastizales y matorrales, desde Jujuy y Salta hasta La Rioja).

Oligoryzomys brendae (Figura 8E)

Nota 8: O. brendae se diferencia de O. flavescens-O. fornesi por su mayor tamaño y orejas más oscuras y de O. chacoensis por su mayor tamaño, coloración dorsal menos anaranjada, ausencia de pelos completamente blancos en mentón y garganta y de parches anaranjados por delante de las orejas.

28a. Tamaño pequeño $(C C=60-100 ; C=94-137 ; P=22-27$; $\mathrm{O}=12-16)$; dorso castaño anaranjado a castaño grisáceo, con el vientre blanquecino, variablemente lavado de gris o amarillo; flancos anaranjados o no; cola bicolor; orejas cubiertas por pelitos ocres o castaños. (bosques, pastizales, pajonales, matorrales y bordes de campos cultivados; también en baldíos, basurales, bordes de arroyos y terraplenes de ferrocarril en áreas urbanas y suburbanas, desde el norte de Argentina hasta Mendoza, La Pampa y Buenos Aires)

Oligoryzomys flavescens (incluyendo O. f. occidentalis)-O. fornesi (Figura 8D)

Nota 9: las especies en este grupo son difíciles de diferenciar entre sí, pero se distinguen de otras simpátridas como O. brendae, O. chacoensis y O. nigripes por su menor tamaño y sus orejas más claras.

29. Tamaño pequeño ( $C C=68-83 ; C=94-117 ; P=20-23 ; O$ = 16-19); pelaje largo y suave, dorsalmente marrón grisáceo a oliváceo, bien separado del vientre; una mancha alrededor de la nariz y boca, de color blanco, se extiende casi hasta el ojo; parche de pelos blanquecinos arriba y debajo de cada ojo; orejas muy grandes, con parches postauriculares conspicuos de color blanco; cola muy larga (140-160\% de la longitud conjunta de la cabeza más el cuerpo), moderadamente peluda, apenas bicolor y terminada en un pincel de pelos de 8-10 $\mathrm{mm}$; manos y patas cubiertos por pelitos blancos; patas alargadas, con las plantas desnudas (medanales, arbustales y algarrobales en bordes de salares del centro-oeste de Argentina, desde La Rioja hasta San Luis)........Salinomys delicatus (Figura 6F)

29a. Pelaje largo y laxo; coloración dorsal marrón grisácea a anaranjada, más pálida hacia los flancos, pero bien contrastada con el vientre, que es de color blanco puro; parches postauriculares y subauriculares blancos, igual que el extremo de la nariz y área alrededor de la boca; orejas grandes y poco peludas; cola casi tan larga o apenas más larga que la longitud conjunta de la cabeza más el cuerpo, bicolor y más oscura hacia la punta, terminada o no en un pequeño pincel de pelos (3-9 $\mathrm{mm}$ ); manos y patas cubiertos por pelitos blancos; plantas desnudas. Andalgalomys 30

30. Tamaño pequeño ( $C C=80-119 ; C=92-127 ; P=22-25$; $\mathrm{O}=18-20)$; pelaje dorsal marrón rojizo; cola sin pincel de pelos evidente (matorrales en el Chaco Seco en Salta y Santiago del Estero).. Andalgalomys pearsoni

30a. Tamaño pequeño ( $C C=75-113 ; C=85-126 ; \mathrm{P}=21-25$; $\mathrm{O}=17-23)$; pelaje dorsal marrón amarillento a marrón grisáceo; cola terminada en un pincel de pelos moderado (áreas arbustivas abiertas del Chaco Seco y Monte, desde Catamarca hasta el norte de Mendoza y San Luis) .Andalgalomys olrogi (Figura 6E)

31. Tamaño grande $(C C=140-172 ; C=165-195 ; P=28-34$; $\mathrm{O}=23-29)$; pelaje denso y suave, dorsalmente castaño

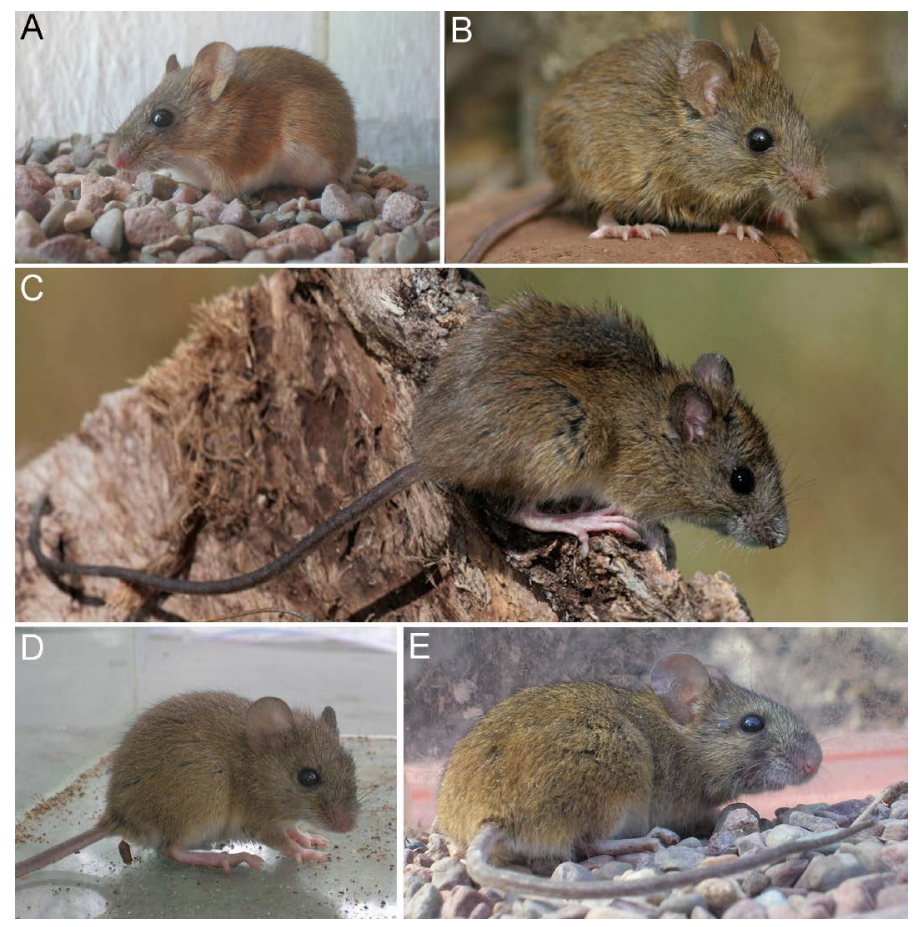

Figura 8. Aspecto externo de Oligoryzomys chacoensis (A), Oligoryzomys nigripes (B), Oligoryzomys longicaudatus (C), Oligoryzomys flavescens occidentalis (D) y Oligoryzomys brendae $(\mathrm{E})$. Las fotos no están en escala. 
anaranjado, contrastando con el vientre, que es blanquecino a crema; garganta completamente blanca; ojos grandes; orejas largas, ovaladas y de color marrón; vibrisas mistaciales y superciliares largas, que extendidas hacia atrás sobre las mejillas sobrepasan el borde externo de la oreja y en algunos casos alcanzan el hombro; patas proporcionalmente cortas y anchas, con una mancha oscura dorsal; dedos cubiertos por pelos grises o blancos; palmas y plantas desnudos, con almohadillas grandes y planas; pelos ungueales claros; garras cortas y recurvadas, cola gruesa, más larga que la longitud conjunta de la cabeza más el cuerpo (110-135\%), unicoloreada, con escamado dérmico evidente y terminada en un pincel de pelos de hasta $10 \mathrm{~mm} ; 6$ pares de mamas (áreas forestadas de Yungas en Jujuy y Salta)..

Rhipidomys austrinus (Figura 9A)

31a. Combinación de caracteres no como en la opción anterior.. 32

32. Coloración dorsal con tonos castaño amarillentos a marrón rojizos; si es marrón grisáceo entonces tiene el rinario y las orejas teñidos de rojizo; cola escasamente cubierta de pelos, con escamado dérmico visible y no terminada en un pincel de pelos. Mayormente restringidos a áreas forestadas subtropicales en el norte de Argentina.

32a. Coloración dorsal marrón grisácea a marrón oscura, variablemente lavada de oliváceo o amarillo; cola moderadamente a densamente cubierta de pelos, con escamado dérmico mayormente oculto y usualmente terminada en un pincel de pelos más oscuros. Principalmente en estepas arbustivas y herbáceas, roquedales y bosques xerófilos. . .36

33. Tamaño mediano ( $C C=139-151 ; C=166-176 ; P=28-30$; $\mathrm{O}=20-22$ ); pelaje suave y abundante, dorsalmente marrón grisáceo, más pálido hacia los flancos; vientre blanquecino lavado de amarillo, bien contrastado con el color del dorso; parches de pelos completamente blancos en garganta y pecho; abdomen, porción interna de las patas, áreas inguinal y perianal con tonos anaranjados; rinario y orejas teñidos de rojizo; orejas relativamente largas y ovaladas; vibrisa genal 2 presente; cola unicolor, marrón clara, con escamado epidérmico evidente; patas cortas y anchas, cubiertas dorsalmente por pelos marrones; pelos ungueales largos y abundantes; garras cortas; plantas desnudas, con almohadillas grandes y redondeadas (Figura 9D); 4 pares de.

..ecomys franciscorum (Figura 9C)

33a. Combinación de caracteres no como en la opción anterior.. .34

34. Tamaño grande $(C C=164-194 ; C=191-230 ; P=35-41$; $\mathrm{O}=22-26$ ); pelaje dorsal marrón rojizo, más o menos lavado de gris o amarillento según los individuos; vientre blancuzco o amarillento, bien separado del dorso; orejas pequeñas, que dobladas hacia delante no cubren los ojos; dorso de las manos y patas cubiertos por pelitos marrones; plantas desnudas, pero densamente escuteladas (cubiertas de escamas); garra del dedo I de la pata trasera extendida hasta la mitad de la primer falange del dedo Il; garra del dedo V extendida hasta o apenas por detrás de la primera articulación interfalangeana del dedo IV; cola muy larga y unicolor; 4 pares de mamas (selvas y bosques en galería desde Misiones y Formosa hasta Entre Ríos)...............Sooretamys angouya (Figura 9B)

34a. Tamaño mediano; pelaje dorsal de color marrón lavado de amarillento o rojizo, según las especies; vientre blanco-grisáceo, bien contrastante respecto del dorso; orejas grandes, que dobladas hacia delante alcanzan los ojos; manos y patas cubiertos por pelitos color blanquecino o crema; plantas desnudas, pero escuteladas; garra del dedo I de la pata trasera extendida apenas por delante de la base de la primer falange del dedo II; garra del dedo $V$ extendida hasta la mitad de la primer falange del dedo IV; cola apenas más larga que la longitud conjunta de la cabeza más el cuerpo y bicolor; 4 pares de mamas. Euryoryzomys 35

35. Tamaño mediano ( $C C=87-185 ; C=118-161 ; P=30-37$; $\mathrm{O}=21-27$; ; coloración dorsal marrón rojiza, lavada de anaranjado hacia los flancos (pudiendo formar una línea brillante desde las mejillas a la cola) (selvas y bosques de Yungas en Salta y Jujuy).

..Euryoryzomys legatus (Figura 7D)

35a. Tamaño mediano ( $C C=118-146 ; C=114-156 ; P=29-33$; $\mathrm{O}=20-23$ ); coloración dorsal castaño oscura, lavada de anaranjado hacia los flancos (selvas en Misiones) ............. Euryoryzomys russatus (Figura 7C)

36. Pelaje denso y suave; vientre grisáceo, con o sin faja pectoral; línea lateral ocrácea más o menos definida; vibrisas largas, pero que no alcanzan a sobrepasar el borde posterior de la oreja; orejas marrones; manos

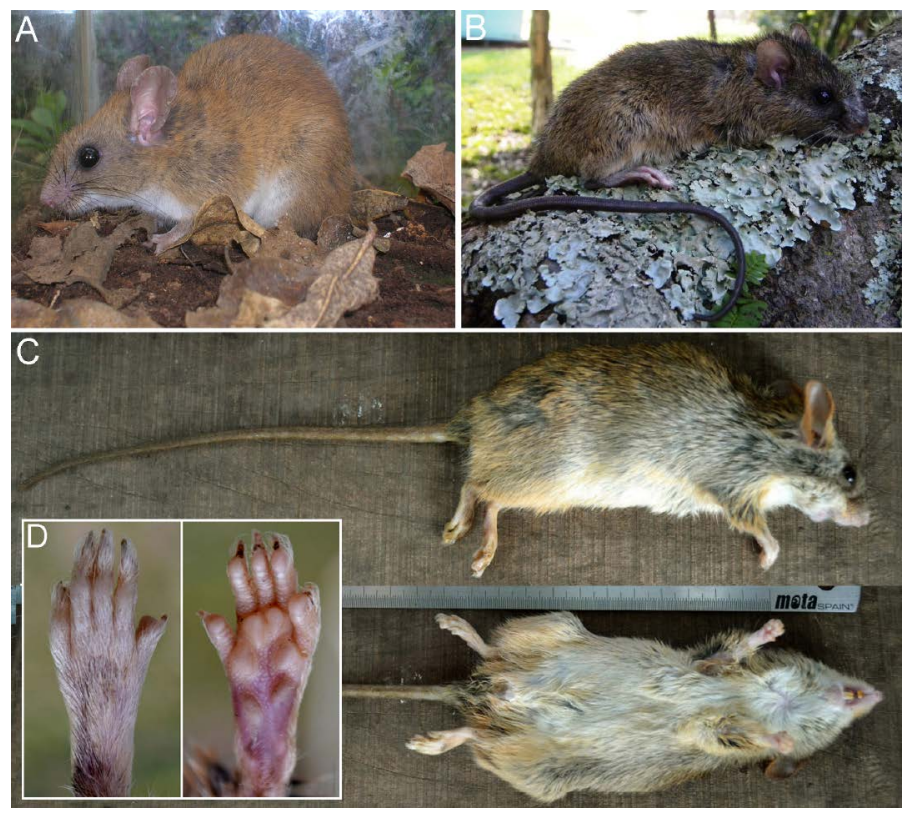

Figura 9. Aspecto externo de Rhipidomys austrinus (A), Sooretamys angouya (B) y Oecomys franciscorum ( $C$ y D; en D se muestra la pata trasera en vista dorsal [izquierda] y plantar [derecha]). Las fotos no están en escala. 
y patas cubiertas por pelitos blancos, mancha de pelos más oscuros sobre el dorso de la pata presente - ausente; pelos ungueales blancos, que cubren parcialmente las garras; cola bicolor y moderadamente peluda Tapecomys 37

Nota 10: las especies de Tapecomys pueden ser difíciles de diferenciar externamente de Phyllotis y Graomys, de las que se distinguen por su coloración sin tintes anaranjados.

36a. Similar al anterior, pero con la coloración más brillante, usualmente teñida de anaranjado o amarillo hacia los flancos y con las patas sin manchas oscuras; vientre grisáceo o completamente blanco . .38

37. Tamaño mediano ( $C C=124-139-; C=136-143 ; P=29-34$; $\mathrm{O}=25-28$; ; coloración dorsal marrón, más oscura hacia la línea media y amarillenta hacia los flancos; una mancha de pelos marrones en el dorso de la pata, cercana a la base de los dedos (áreas forestadas de Yungas en Jujuy) ..Tapecomys primus

37a. Tamaño mediano (CC $=122-134-; C=121-145$; $P=$ 26-28; $\mathrm{O}=24-25)$; coloración dorsal castaño grisácea, más pálida y amarillenta hacia los flancos y gris hacia los lados de la cabeza; vientre gris; hocico amarillento (conocido para una sola localidad en Salta, en pastizales de altura de Yungas a $2100 \mathrm{msnm}$ ).

Tapecomys wolffsohni

38. Pelaje moderadamente largo y suave; orejas medianas a grandes, poco peludas y ovaladas; ojos grandes; talones sin pelos; pelos ungueales abundantes y blancos, que cubren parcialmente las garras; cola generalmente bicolor y poco peluda, usualmente terminada en un pincel de pelos oscuros; 4 pares de mamas; comportamiento generalmente agresivo; bordes supraorbitarios del cráneo posteriormente divergentes y bien marcados, palpables externamente Graomys 39

38a. Pelaje moderadamente largo y suave; orejas medianas a grandes, poco peludas y ovaladas; cabeza y ojos grandes; faja pectoral (Figura 11) de pelos anaranjados presente (e. g., P. caprinus, algunas poblaciones de $P$. tucumanus y de $P$. xanthopygus) o ausente ( $P$. alisosensis, $P$. anitae, $P$. bonariensis); talones cubiertos de pelos; pelos ungueales abundantes y blancos, que cubren parcialmente las garras; cola generalmente bicolor y poco peluda, con o sin pincel terminal de pelos. Comportamiento no agresivo; bordes supraorbitarios del cráneo no palpables externamente Phyllotis 42

39. Tamaño pequeño $(C C=108 ; C=127 ; P=25 ; O=20)$; $L T$ $\sim 235 \mathrm{~mm}$; sin línea amarillenta sobre los flancos y con pincel de pelos en la cola menos notable (conocido únicamente de la localidad tipo y cercanías, en el extremo sur de la Sierra de Ambato, Catamarca, entre 400 y 3,000 msnm) Graomys edithae

39a. Tamaño mediano (LT $>\mathbf{2 6 0} \mathbf{~ m m}$ ), usualmente con una línea amarillenta o anaranjada brillante sobre los flancos y con pincel de pelos en la cola más notable . .40
40. Tamaño mediano ( $C C=131-161 ; C=149-184 ; P=30-35$; $\mathrm{O}=$ 25-27); coloración dorsal castaña, lavada de ocre hacia los flancos; vientre blanco grisáceo, lavado de amarillento o crema, con pelos completamente blancos en la garganta; orejas marrones; cola bicolor, terminada en un pincel de pelos poco evidente; patas blanquecinas (zonas de transición entre bosques pedemontanos de Yungas y bosques chaqueños en Jujuy, Salta y Tucumán) Graomys domorum (Figura 10B)

40a. Coloración dorsal marrón amarillento a marrón grisáceo, lavado de amarillo o anaranjado hacia los flancos; vientre completamente blanco o con pelos individuales de base gris y punta blanca, pero siempre bien contrastante con el dorso; patas dorsalmente blancas, con las plantas oscuras; cola bicolor, con pincel terminal de pelos conspicuo.

41. Tamaño mediano $(C C=111-165 ; C=114-185 ; P=$ 26-33; $0=20-25$ ), pero en general más pequeño que G. griseoflavus; coloración más brillante, menos ocrácea y con el vientre siempre blanco (áreas boscosas y arbustivas del Chaco Seco y Húmedo y Espinal).............................Graomys chacoensis (Figura 10C)

41a. Tamaño mediano ( $C C=118-169 ; C=134-171$; $P=$ 27-31; $O=23-25$ ), pero en general más grande que $G$. chacoensis y con la coloración menos brillante; vientre completamente blanco o con pelos de base gris y punta blanca (áreas boscosas y arbustivas en el oeste y sur de Argentina, principalmente en el Monte y Estepa Patagónica, aunque también en el Espinal, desde Salta hasta Santa Cruz).........Graomys griseoflavus (Figura 10D)

42. Tamaño pequeño a mediano ( $C C=82-144 ; C=89-139 ; P$ $=27-31 ; O=18-24) ;$ coloración general marrón oscura a casi negra; vientre ocre $o$ acanelado, que no contrasta fuertemente con el dorso; orejas oscuras y poco cubiertas de pelo; manos y patas cubiertas por pelitos blancos; cola bicolor (áreas ecotonales entre pastizales de altura y bosques montanos de Yungas, por encima de los 1,200 msnm en Tucumán) Phyllotis anitae

42a. Coloración general comparativamente más clara, marrón grisáceo, a veces lavada de amarillento; vientre blanco grisáceo, que contrasta más notablemente con el dorso.

43. Tamaño mediano $(C C=127-151 ; C=110-147 ; P=25-28$; $\mathrm{O}=23-25)$; dorso marrón amarillento, más pálido hacia los flancos, pero bien separado del vientre; región ventral gris blanquecino, a veces lavada de amarillento; faja pectoral ausente o muy poco definida; manos y patas cubiertos dorsalmente por pelitos blanco sucio; cola bicolor y poco peluda (roquedales en Sierra de la Ventana, sudoeste de Buenos Aires)......Phyllotis bonaeriensis

43a. Distribución distinta de la opción anterior.

44. Tamaño mediano $(C C=102-140 ; C=116-151 ; P=21-23$; $\mathrm{O}=19-24)$; coloración dorsal marrón grisácea lavada de amarillento, más brillante hacia los flancos y meji- 


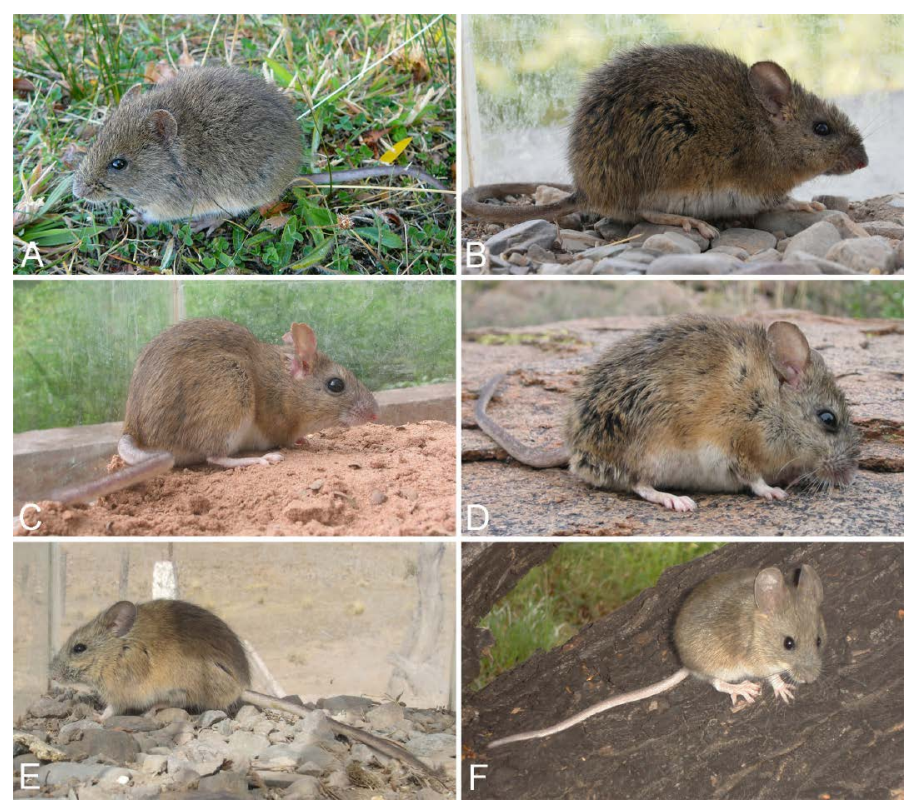

Figura 10. Aspecto externo de Loxodontomys micropus (A), Graomys domorum (B), Graomys chacoensis (C), Graomys griseoflavus (D), Phyllotis tucumanus (E) y Phyllotis xanthopygus (F). Las fotos no están en escala.

llas, que están teñidos de anaranjado; vientre blanco-grisáceo (áreas arbustivas y de pastizales asociadas a roquedales en la Prepuna y Puna, por encima de los 2,000 msnm, en Jujuy) Phyllotis caprinus

Nota 11: P. caprinus es simpátrica con $P$. xanthopygus en Jujuy, pero se distingue por su mayor tamaño, sus orejas comparativamente más pequeñas, la cola más gruesa y menos peluda y por presentar usualmente una faja pectoral anaranjada.

44a. Coloración, medidas y/o distribución no como en la opción anterior. . .45

45. Tamaño mediano ( $C C=104-142 ; C=107-145 ; P=24-30$; $\mathrm{O}=$ 22-29); coloración dorsal marrón clara o grisácea, lavada de amarillento, más brillante hacia los flancos y mejillas, que pueden o no estar teñidos de anaranjado; vientre blanco-grisáceo, a veces lavado de amarillento; faja pectoral mayormente ausente; orejas generalmente mayores de $24 \mathrm{~mm}$; cola bicolor, sin escamado visible y terminada en un pincel de pelos oscuros (Figura 11); manos y patas cubiertos por pelitos blanco sucio (roquedales en áreas altoandinas y puneñas, pastizales de altura en el Monte y el Chaco Seco, y en estepas de la Patagonia, desde Salta y Jujuy hasta Santa Cruz).

Phyllotis xanthopygus (Figura 10F)

Nota 12: evidencias genéticas y morfológicas sugieren que el actual concepto de $P$. xanthopygus se corresponde con un complejo de especies. En Argentina, este complejo estaría representado por al menos 5 entidades morfológicamente crípticas, con diferencias cualitativas y cuantitativas sutiles.

45a. Dorso marrón grisáceo, lavado de amarillento; flancos y mejillas teñidos de anaranjado; vientre blanco grisáceo; faja pectoral casi constantemente presente; cola menos peluda y casi sin pincel; orejas proporcional- mente más cortas (usualmente $<24 \mathrm{~mm}$ ) y más oscuras (especialmente hacia el borde) que en $P$. xanthopygus (Figura 11) (selvas de Yungas y pastizales húmedos asociados a Yungas y Monte, en el noroeste de Argentina)

46. Tamaño mediano ( $C C=118-137 ; C=125-137 ; P=32-33$; $\mathrm{O}=22-24$ ); muy difícil de distinguir de $P$. tucumanus, de la que apenas se diferencia por su tamaño algo mayor, su pelaje más largo, oscuro y de tonalidades más intensas, la presencia de un anillo periocular más contrastante, los flancos más anaranjados y el vientre más ocráceo (selvas y bosques de Yungas hasta el ecotono con pastizales montanos en el centro y sur de la Sierra de Zenta, entre 1,200 y 3,100 msnm, en Jujuy y Salta) ....

...Phyllotis nogalaris

46a. Tamaño mediano (CC = 95-129; $C=108-132 ; \mathrm{P}=27-32$; $\mathrm{O}=21-23$ ); coloración general más clara y de tonos menos intensos que en $P$. nogalaris (pastizales montanos húmedos desde Jujuy y Salta hasta Catamarca) ...

Phyllotis tucumanus (Figura 10E)

47. Tamaño pequeño, cuerpo robusto, cola corta y hocico corto, pero abultado y de tono rosado intenso; márgenes de la boca cubiertos por pelitos cortos y rígidos de color blanco; pelaje suave, dorsalmente castaño oscuro, con efecto agutí fino pero visible; línea media dorsal casi negra; laterales castaño-amarillento y vientre gris claro; orejas medianas; ojos pequeños; cola bicolor, gris oscura por arriba y blanquecina por debajo, con anillado epidérmico notorio; manos y patas cubiertos por pelitos grises, pero que dejan ver la piel rosada por debajo; uñas medianamente desarrolladas ... Bibimys (Figura 12C) 48

47a. Hocico no abultado, ni rosado intenso. .49

48. Tamaño pequeño $(C C=94-107 ; C=70-75 ; P=21-22,5 ; O$ = 14-17); indistinguible de $B$. torresi, excepto por su distribución (pastizales periselváticos del Chaco Húmedo y sur de Misiones). Bibimys chacoensis (Figura 12C)

48a. Tamaño pequeño $(C C=84-97 ; C=65-78 ; P=22-23 ; O$ = 15-17); indistinguible de $B$. chacoensis, excepto por su distribución (bosques ribereños, pastizales, espadañales y pajonales en terrenos inundables de la porción media e inferior del Delta del Paraná).. Bibimys torresi

49. Tamaño pequeño ( $C C=78-92 ; C=35-46 ; P=17-21 ; O$ = 6-8); pelaje corto y sedoso, dorsalmente marrón amarillento, con tintes anaranjados hacia los flancos y netamente separado del blanquecino del vientre; rinario conspicuo y rosado, con los lados del hocico de color anaranjado; orejas rudimentarias, completamente cubiertas por el pelo de la cabeza y apenas indicadas externamente por un penacho de pelitos blancos; ojos medianos; manos y patas cubiertos por pelitos anaranjados; dedos blancos; manos con garras muy desarrolladas ( 4-5 mm), transversalmente comprimidas y con una quilla que se extiende desde la base hasta ca. 

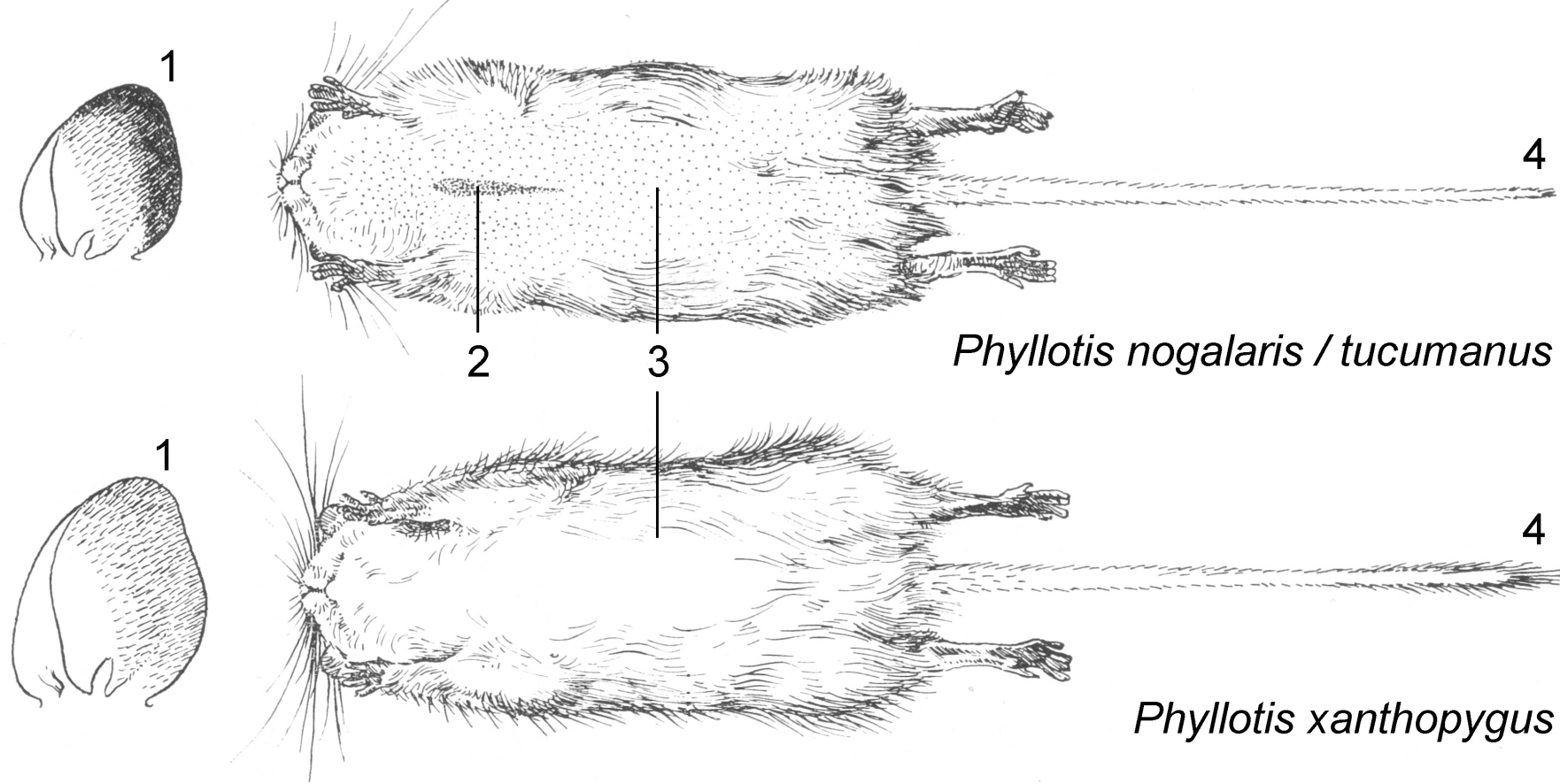

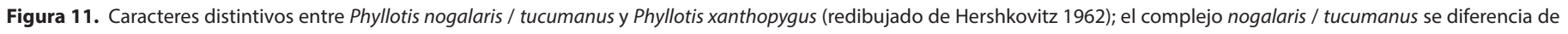

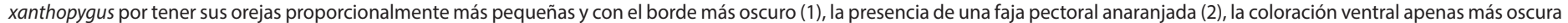
(3), y la cola sin pincel de pelos (4). Las figuras no están en escala.

la mitad de cada uña; patas con un fleco o peine de pelos blancos sobre cada lado; cola muy corta y blanquecina, apenas más oscura por encima y cubierta de pelos en la base (estepas arbustivas y herbáceas de Patagonia, desde Río Negro hasta Santa Cruz) ..Notiomys edwardsii (Figura 13G)

49a. Orejas desde muy pequeñas a grandes, pero no rudimentarias (siempre visibles externamente) y sin penacho de pelos

50. Tamaño pequeño, con aspecto general de musaraña; hocico moderadamente aguzado; ojos y orejas pequeños, mayormente ocultos entre los pelos de la cabeza; cola muy corta $(<50 \%$ de la longitud conjunta de la cabeza más el cuerpo); pelaje corto, de aspecto aterciopelado; coloración general oscura, marrón a negruzca; garras de las manos bien desarrolladas, casi tan largas o más que el dedo correspondiente..

50a. Sin aspecto de musaraña..

51. Tamaño pequeño ( $C C=99-116 ; C=30-52 ; P=16-21$; $\mathrm{O}=8-10$ ); pelaje corto, híspido y brillante; coloración general negruzca a castaño oscuro, apenas más clara en el vientre; extremo del hocico generalmente blanquecino; cola negra, cubierta por pelitos cortos, pero con las escamas visibles; manos y patas cubiertos por pelitos castaños; palmas y plantas escamadas, con almohadillas plantares pequeñas (selvas en Misiones).

Blarinomys breviceps (Figura 14)

51a. Tamaño pequeño; pelaje corto, fino y denso; coloración dorsal marrón o negruzca, a veces lavada de castaño o de oliva, poco o moderadamente contrastada con el vientre, que suele ser de color grisáceo; cola corta, robusta y densamente cubierta de pelos, ocultando las escamas; manos y pies proporcionalmente cortos y anchos; garras bien desarrolladas, transversalmente comprimidas y con una quilla que se extiende desde la base hasta ca. la mitad de cada uña (bosques y estepas ecotonales de la Patagonia)............Geoxus (Figura 14) 52

52. Tamaño pequeño ( $C C=100-110 ; C=39-51 ; P=20-22$; $\mathrm{O}=10-12$ ); coloración dorsal marrón, con tintes oliváceos o amarillentos; vientre gris, bien separado del dorso (matorrales ecotonales en Santa Cruz)

Geoxus michaelseni

52a. Tamaño pequeño ( $C C=95-100 ; C=30-44 ; P=18-20$; $\mathrm{O}=10-12)$; coloración general marrón oscura a casi negra, a veces lavada de castaño en el dorso, más clara hacia el vientre (bosques y matorrales ecotonales desde el centro-oeste de Neuquén hasta por lo menos el sudoeste de Chubut). Geoxus valdivianus

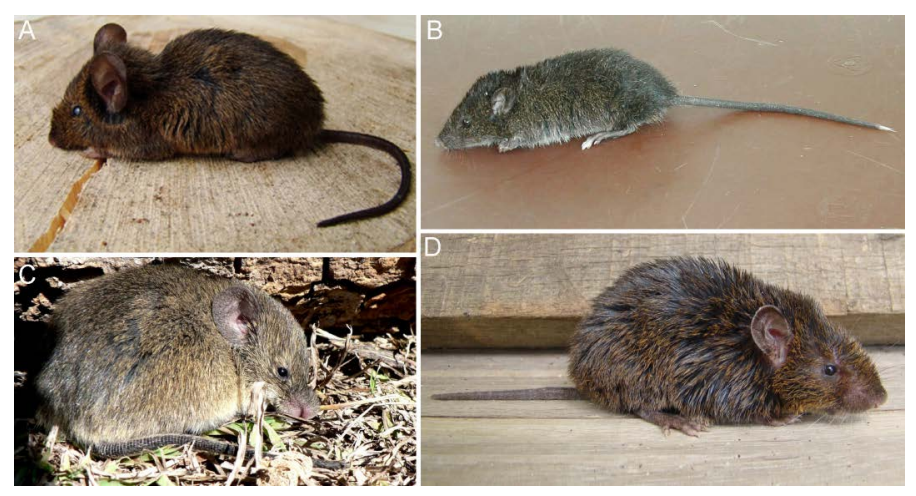

Figura 12. Aspecto externo de Castoria angustidens (A), Deltamys kempi (B), Bibimys chacoensis (C) y Thaptomys nigrita (D). Las fotos no están en escala. 
53. Tamaño mediano ( $C C=100-130 ; C=47-59 ; P=23-27$; $\mathrm{O}=11-17)$; contextura robusta; pelaje corto y suave, dorsalmente marrón amarillento a marrón muy oscuro, con el vientre gris o blanco grisáceo; orejas pequeñas y redondeadas; ojos medianos; manos con garras muy desarrolladas ( $>4 \mathrm{~mm}$ ), transversalmente comprimidas y con una quilla que se extiende desde la base hasta ca. la mitad de cada uña; patas anchas y robustas, con las palmas y las plantas desnudas, cubiertas por seis almohadillas grandes, redondeadas y prominentes; borde externo de la pata con un peine de pelos evidente (estepas herbáceas y arbustivas, matorrales y bosques; principalmente en áreas cordilleranas y pedemontanas, desde el centro de Mendoza, por el oeste, hasta el sur de Santa Cruz). Paynomys macronyx (Figura 13H)

53a. Combinación de caracteres no como en la opción anterior.. 54

54. Hocico característicamente alargado (aunque no siempre de forma evidente en los ejemplares juveniles); garras de las manos bien desarrolladas.

55

54a. Hocico nada o apenas alargado; garras de las manos poco o bien desarrolladas.

55. Tamaño pequeño ( $C C=93-113 ; C=83-90 ; P=23-25$; $\mathrm{O}=16-19)$; pelaje dorsal fino y suave, castaño a gris; vientre grisáceo o marrón, lavado de amarillento; orejas medianas; ojos pequeños, mayormente ocultos en el pelaje de la cabeza; en algunos ejemplares los pelos

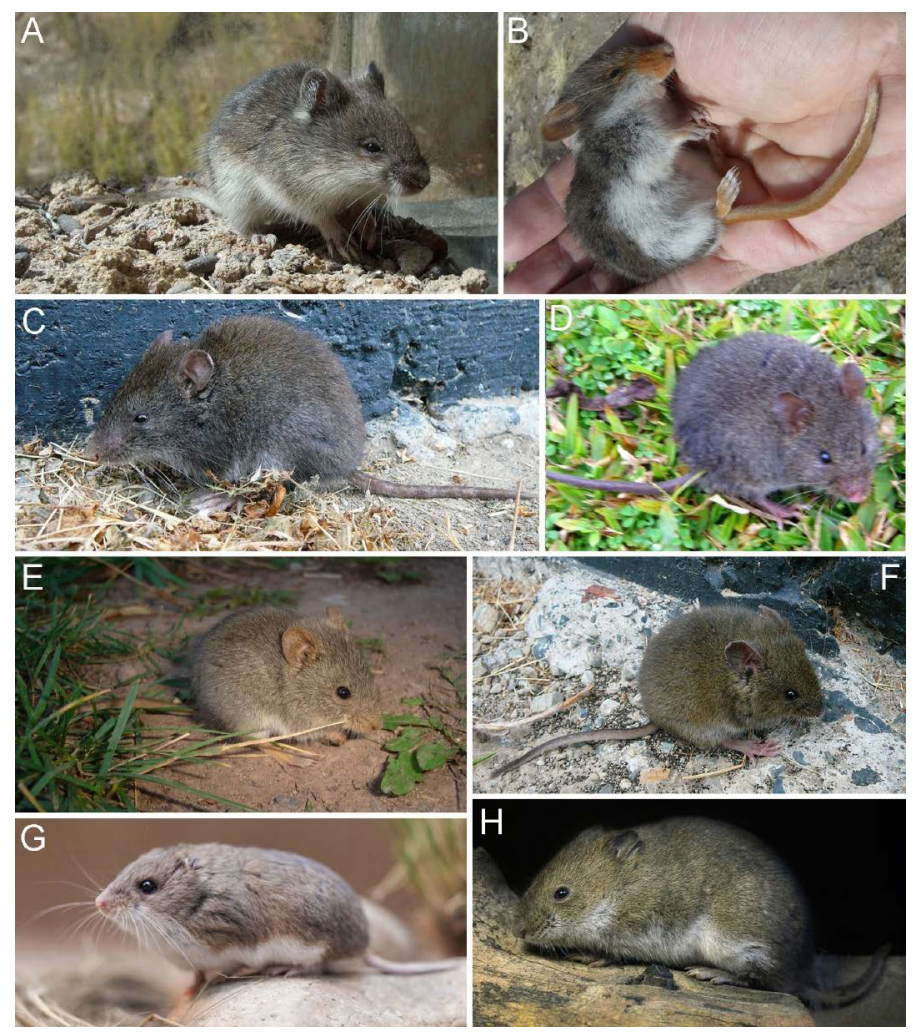

Figura 13. Aspecto externo de Akodon albiventer (A), Abrothrix jelskii (B), Abrothrix hirta (C), Abrothrix illutea (D), Abrothrix olivacea (E y F; en E se destaca la coloración típica de los ejemplares de estepa y en F la de los bosques), Notiomys edwardsii (G) y Paynomys macronyx $(\mathrm{H})$. Las fotos no están en escala.
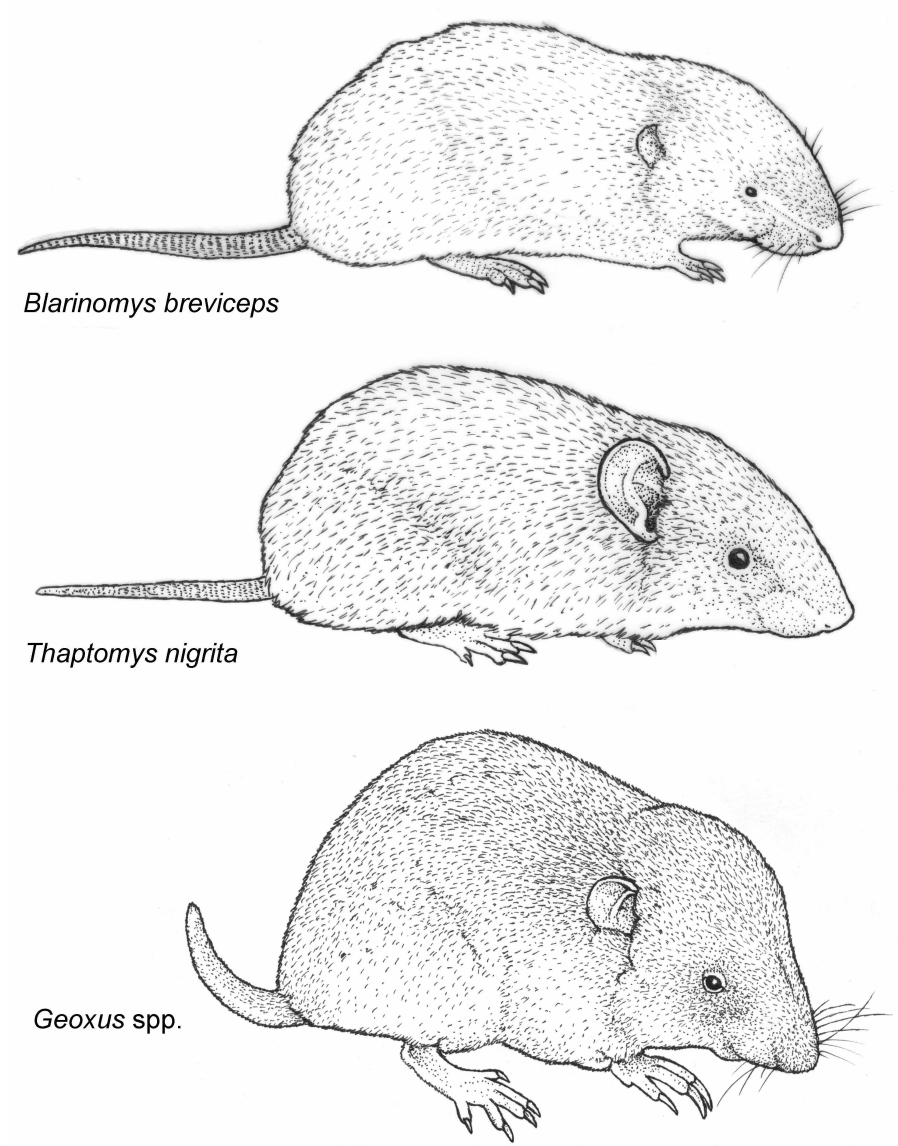

Figura 14. Aspecto externo de tres roedores sigmodontinos semifosoriales; nótense las diferencias en el tamaño de los ojos, orejas y garras de las patas delanteras.

de la punta de la nariz y barbilla son blancos o amariIlentos; manos y patas cubiertas por pelitos blanquecinos, marrones o grises; uñas de las manos alargadas y curvas (2.3-2.6 $\mathrm{mm}$ ) (Figura 2L); dedo V del pie largo, su extremo sobrepasa el punto de inserción de los dedos II-IV (Figura 15); cola bicolor o marrón uniforme, poco pilosa y con el anillado epidérmico notorio; 3 pares de mamas (selvas en Misiones) ...

..Brucepattersonius iheringi (Figura 16E)

Nota 13: las especies de Brucepattersonius se suelen confundir con las formas selváticas del género Akodon (i. e., A. montensis y A. paranaensis), pero se diferencian de aquellas por su menor tamaño y sus ojos conspicuamente más pequeños y ocultos entre los pelos de la cabeza.

55a. Tamaño mediano a grande; cola relativamente gruesa; orejas cortas y redondeadas; coloración general marrón o incluso negra en algunas especies, con tonalidades rojizas y en algunos casos anaranjada, más clara en el vientre, con las bases de los pelos siempre grises; cola cubierta por escamas anulares grandes y escasamente peluda; patas robustas; dedo $\mathrm{V}$ del pie más corto, su extremo no sobrepasa el punto de inserción de los dedos II-IV (Figura 15); en la mano, la uña del dedo III es casi tan larga como el mismo dedo; la uña del dedo V se extiende hasta la base del dedo IV y la del dedo 

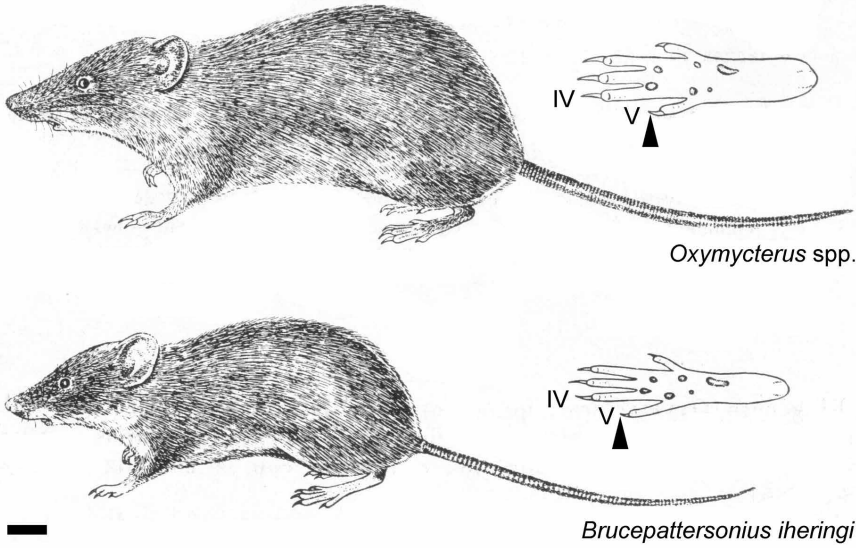

Figura 15. Aspecto externo en Oxymycterus spp. y Brucepattersonius iheringi (redibujado de Massoia 1969); se destaca la distinta longitud del dedo $\mathrm{V}$ con respecto al dedo IV (flecha) en las patas traseras de ambos taxones. La escala es igual a $10 \mathrm{~mm}$.

I apenas alcanza los carpales (Figura 2M); 4 pares de mamas Oxymycterus (Figura 16A-C) 56

56. Tamaño mediano ( $C C=114-145 ; C=70-97 ; P=28-32 ; O$ = 17-21); coloración general negruzca, lavada de ocre o rojizo; el dorso de las patas traseras y la cara interna de las orejas están cubiertas por pelitos negros; cola casi negra, apenas más clara por debajo; en la barbilla y a veces en la garganta hay una característica mancha blanca; garras de las patas anteriores notablemente desarrolladas (largas y robustas) (selvas y Bosques Montanos del extremo sur de Yungas y su ecotono con pastizales de altura, entre 800 y 3,000 msnm, en el sur de Salta, Catamarca y Tucumán)................ Oxymycterus wayku

57. Longitud CC >160 (CC = 170-180; $C=110-120 ; P=27-40$; $\mathrm{O}=19-22)$; coloración general marrón rojiza, con tintes metálicos sobre la línea media; flancos anaranjados o marrón-amarillentos; vientre gris, lavado de ocre; cola y orejas marrón oscuras (selvas en Misiones)

Oxymycterus quaestor (Figura 16A)

57a. Longitud CC $<160 \mathrm{~mm}$. 58

58. Tamaño mediano ( $C C=105-153 ; C=66-115 ; P=25-35 ; O$ = 18-22); coloración dorsal marrón olivácea a negruzca (en algunos ejemplares de Jujuy), con pelos negros entremezclados y lavada de rojizo hacia las ancas; vientre gris amarillento; usualmente con una mancha oscura por encima del rinario (selvas y bosques montanos de Yungas, y áreas de ecotono con pastizales de altura, en Jujuy, Salta y el extremo norte de Tucumán)

Oxymycterus paramensis (Figura 16C)

58a. Tamaño mediano ( $C C=134-150 ; C=81-10 ; P=27-32$; $\mathrm{O}=15-19)$; coloración general fuertemente rojiza, con pelos negros entremezclados; vientre anaranjado a castaño; cola y orejas marrón oscuras (pastizales y pajonales densos, especialmente en áreas cercanas a cuerpos de agua, permanentes o temporarios, desde Misiones y Corrientes hasta el sur de Santa Fe y norte, este y sur de Buenos Aires; también en pastizales de ambientes serranos de Córdoba y San Luis) Oxymycterus rufus (Figura 16B)

59. Tamaño grande, CC generalmente $>150 \mathrm{~mm}$. .60

59a. Tamaño mediano a pequeño, CC generalmente $<150$ $\mathrm{mm}$ )

60. Tamaño grande $(C C=135-185 ; C=102-164 ; P=22-37 ; O$ = 22-34); pelaje fino, largo y suave, de color gris amarronado en el dorso, más oscuro hacia la línea media y lavado de ocre hacia los flancos; vientre gris blanquecino, a veces con tintes amarillentos; orejas medianas y redondeadas, de color marrón oscuro; cola bicolor, marrón oscuro por arriba y blanquecina por debajo (a veces con una línea media ventral fina y oscura que corre desde la base hasta cerca del ápice); manos y patas cubiertos por pelitos blanquecinos; palmas y plantas desnudas, con almohadillas grandes, redondeadas y prominentes; garras delanteras muy cortas; 4 pares de mamas; en vista frontal, el extremo distal de los incisivos superiores tiene forma de bisel (pastizales y matorrales en ambientes Altoandinos y de la Puna, Selvas y pastizales húmedos de Yungas, entre 500 y 4800 msnm, en Jujuy, Salta, Tucumán y Catamarca) ..... Andinomys edax (Figura 5A)

60a. Garras delanteras casi tan largas como el dedo correspondiente y apenas recurvadas

61. Tamaño grande ( $C C=152-198 ; C=132-159 ; P=34-38$; $\mathrm{O}=19-24)$; pelaje fino, suave y brillante; coloración dorsal marrón oscura a negra; vientre blanco grisáceo, con la línea que lo separa del dorso moderadamente delimitada; orejas comparativamente pequeñas, redondeadas y densamente cubiertas de pelos oscuros; manos y patas cubiertos dorsalmente por pelitos blanquecinos; pelos ungueales cortos, pero abundantes; almohadilla hipotenar vestigial o ausente (Figura 2J); cola corta (entre $65 \%$ y $90 \%$ de la longitud conjunta de la cabeza más el cuerpo) y unicolor, cubierta por pelos oscuros, cortos por arriba y más largos por debajo; 4 pares de mamas (terrenos anegadizos con pajonales densos, desde Formosa y Corrientes hasta el norte y este de Buenos Aires)........Scapteromys aquaticus (Figura 16D)

61a. Tamaño grande ( $C C=225 ; C=110 ; P=43 ; O=$ no disponible); pelaje largo y algo híspido, dorsalmente marrón, con brillo metálico, dorado a verde, a la luz incidida; vientre grisáceo, con la línea que lo separa del dorso no bien delimitada; orejas redondeadas y pequeñas, densamente cubiertas por pelitos cortos de color marrón; cola corta ( $55 \%$ de la longitud conjunta de la cabeza más el cuerpo) y unicolor, negruzca todo alrededor; los pelos que recubren la cola son más largos abajo y a los lados; manos y patas marrón grisáceas, con algunos pelitos plateados; palmas y plantas desnudas, pero con escutelado dérmico notorio; almohadilla hipotenar vestigial (Figura 2I) (especie sólo conocida por un ejemplar, coleccionado a finales del siglo XIX en el noreste del Chaco y probablemente extinta; se desconocen sus 


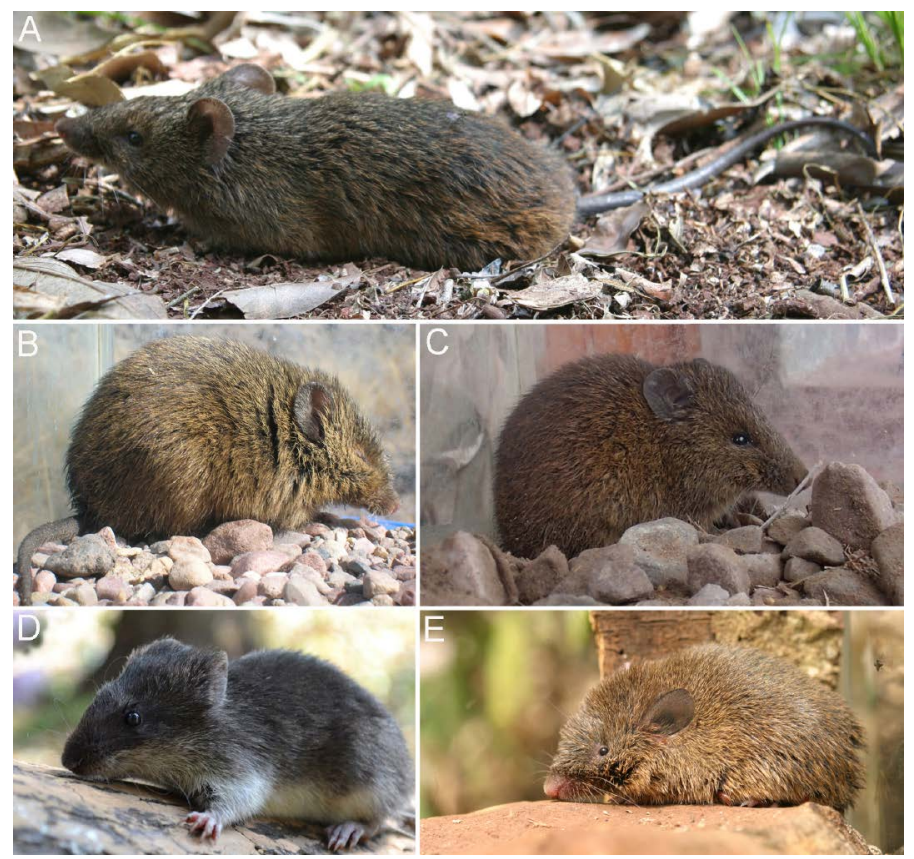

Figura 16. Aspecto externo de Oxymycterus quaestor (A), Oxymycterus rufus (B), Oxymycterus paramensis (C), Scapteromys aquaticus (D) y Brucepattersonius iheringi (E). Las fotos no están en escala.

hábitos, aunque es posible que habitase en pastizales inundables). Gyldenstolpia fronto

62. Tamaño mediano ( $C C=99-144 ; C=80-112 ; \mathrm{P}=25-32 ; \mathrm{O}$ = 15-23); aspecto robusto; pelaje espeso, laxo y suave; dorso marrón, a veces lavado de gris u ocre en el dorso, más claro en los flancos y gris o plomizo, con tintes ocres, en el vientre; orejas medianas de color marrón; cola ( $75 \%$ de la longitud conjunta de la cabeza más el cuerpo) cubierta por pelos ralos y dispersos, marrones sobre la línea media dorsal y más claros hacia los lados y por debajo; patas delgadas, con las palmas y las plantas desnudas; éstas últimas cubiertas por seis almohadillas bajas y grandes; el dedo $V$ del pie es largo y alcanza el extremo distal de la primer falange del dedo IV (bosques, pastizales húmedos y áreas arbustivas de Cordillera hasta 3,000 msnm y pedemonte, desde el sur de Mendoza hasta Santa Cruz)

Loxodontomys micropus (Figura 10A)

Nota 14: Loxodontomys se puede confundir con Phyllotis xanthopygus, del que se diferencia por su cola y orejas más cortas y con Reithrodon y Euneomys, de los que se distingue por su cola más larga y por los incisivos sin surcos anteriores.

62a. Combinación de caracteres no como en la opción anterior..

63. Tamaño pequeño; miembros cortos y orejas medianas $(<20 \mathrm{~mm})$; coloración dorsal y ventral usualmente bien diferenciadas, con el vientre blanco a blanco grisáceo; ojos saltones; parches postauriculares blancos, poco o bien definidos; patas pequeñas, siempre $<23 \mathrm{~mm}$ y dorsalmente cubiertas por pelitos blancos, excepto en los talones que están desnudos; pelos ungueales largos, que sobrepasan pero no ocultan las uñas; cola propor- cionalmente corta, bicoloreada, bien cubierta de pelos, fina y sin pincel terminal; 4 a 7 pares de mamas.

Calomys (Figura 5C-F) 64

63a. Combinación de caracteres no como en la opción anterior

64. Tamaño pequeño a mediano ( $C C=92-119 ; C=65-87 ; P$ = 18-22; $0=16-19)$; coloración dorsal grisácea, lavada de amarillento hacia los flancos; vientre blanco grisáceo, con la línea que lo separa del dorso poco definida; orejas medianas, generalmente $>16 \mathrm{~mm}$, redondeadas y oscuras, con parches postauriculares indistintos; 5 a 7 pares de mamas Calomys spp. (Fig 5F)

Nota 15: en este grupo se incluyen cuatro especies grandes del género Calomys, difíciles de diferenciar en el campo: $C$. fecundus (Yungas y su ecotono con el Chaco Seco, entre 600 y 2,700 msnm, en toda la región noroeste de Argentina), C. callidus (pastizales en el Chaco Húmedo y Mesopotamia), C. callosus (pastizales y pajonales en ambientes chaqueños, desde el este de Salta y Santiago del Estero hasta Formosa y Chaco) y $C$. venustus (pastizales y campos cultivados en Córdoba, San Luis, Santa Fe y Santiago del Estero).

64a. Orejas generalmente $<16 \mathrm{~mm}$.

65. Tamaño pequeño ( $C C=73-79 ; C=40-45 ; P=14-20 ; O$ = 16-17); pelaje denso, suave, largo y sedoso; coloración dorsal marrón grisácea, más oscura hacia la línea media y con aspecto marmolado; vientre blanco; orejas cubiertas por pelitos marrón claro, con parches postauriculares notorios; cola blanquecina y muy corta, apenas amarillenta por encima; plantas desnudas, excepto el talón y su mitad proximal; 4 o 5 pares de mamas. (pastizales de altura de Yungas, Puna y Altos Andes, por encima de los 2,800 msnm, en Jujuy, Salta, Catamarca, y Tucumán) ...........................................Calomys lepidus (Figura 5E)

65a. Sin aspecto marmolado y con la cola proporcionalmente más larga. .66

66. Tamaño pequeño ( $C C=69-108 ; C=77-91 ; P=17-22 ; O$ =13-17); coloración dorsal marrón amarillenta a grisácea, más pálida hacia los flancos, con una línea lateral ocrácea en algunas poblaciones; vientre blanco grisáceo, que contrasta con el dorso, pero sin formar una línea de separación definida; en algunos ejemplares los pelos de la garganta son completamente blancos; orejas medianas, marrón amarillentas; cola corta, $50 \%$ de la longitud conjunta de la cabeza más el cuerpo; 5 o 6 pares de mamas (pastizales, campos cultivados, roquedales y estepas arbustivas desde Jujuy hasta Santa Cruz, desde el nivel del mar hasta 3,900 msnm).

..Calomys musculinus (Figura 5D)

Nota 16: esta especie se diferencia de C. laucha, con la cual convive en un extenso sector del centro y norte de Argentina, por su pelaje más ralo, coloración más clara y menos contrastada entre el dorso y vientre y orejas y cola más largas (Figura 17); C. lepidus es más pequeña, con los parches postauriculares menos definidos y tiene 
la cara interna de las orejas cubierta por pelitos amarillentos (grisáceos en C. musculinus).

66a. Tamaño pequeño; coloración dorsal y ventral bien contrastada; cola $\sim 44 \%$ de la longitud conjunta de la cabeza más el cuerpo.

67. Tamaño pequeño $(C C=57-76 ; C=42-54 ; P=13-15 ; O=$ 12-14); coloración dorsal gris ocrácea a gris pardusca, más oscura hacia la línea media; vientre blanco, bien separado del dorso; garganta y mentón cubiertos a veces por pelos completamente blancos; con parches postauriculares blancos conspicuos; a veces con un mechón de pelos ocres preauriculares; 4 a 5 pares de mamas (pastizales y campos cultivados en el norte $y$ centro de Argentina, normalmente por debajo de los $1,000 \mathrm{msnm}$ ). .Calomys laucha (Figura $5 \mathrm{C}$ )

67a. Tamaño pequeño $(C C=74-88 ; C=38-77 ; P=13-15 ; O=$ 12-14); coloración dorsal amarillenta a marrón oscura, a veces lavada de rojizo o castaño; vientre gris claro, bien separado del dorso; en algunos especímenes el mentón es completamente blanco; anillo periocular marcado o no; parches postauriculares pálidos (pastizales y campos cultivados en Misiones)..........Calomys tener

68. Tamaño pequeño ( $C C=81-111 ; C=39-55 ; P=14-21$; $\mathrm{O}=9-13$ ); pelaje corto, dorsalmente castaño oscuro a marrón oliváceo oscuro (a veces con cierto brillo metálico), más claro hacia el vientre; coloración dorsal y ventral poco diferenciadas; ojos reducidos; orejas pequeñas y redondeadas; manos y patas cubiertas por pelitos castaño oscuro; garras de las manos largas y finas; cola menor que el $\mathbf{5 0} \%$ de la longitud conjunta de la cabeza más cuerpo, oscura, poco pilosa y con el escamado dérmico visible; 4 pares de mamas (selvas en Misiones)

Thaptomys nigrita (Figuras 12D, 14)

Nota 17: Thaptomys se diferencia de las especies selváticas de Akodon (i. e., A. montensis, A. paranaensis) por su coloración más oscura, ojos y orejas más pequeños y su cola proporcionalmente más corta.

68a. Cola mayor que el $50 \%$ de la longitud cabeza-cuerpo

69. Tamaño pequeño $(C C=89-108 ; C=74-87 ; P=20-22$; $\mathrm{O}=12-14$ ); pelaje espeso, fino y suave, con aspecto aterciopelado; coloración dorsal marrón oscura, con tintes oliváceos a ocres en la cabeza y flancos; vientre gris oscuro; patas cubiertas por pelitos gris oscuro; cola marrón oscura, apenas más clara por debajo y cubierta por pelitos finos que no esconden el escamado epidérmico; ojos pequeños; orejas cortas y ovaladas, cubiertas por pelitos oscuros y moderadamente escondidas en el pelaje de la cabeza; algunos ejemplares presentan una mancha blanca en el mentón (pajonales en terrenos anegadizos, pastizales periselváticos y bosques ribereños en el noreste de Buenos Aires y sur de Entre Ríos) ... Deltamys kempi (Figura 12B)

Nota 18: D. kempi se puede confundir con A. azarae, con la cual convive en el noreste de Buenos Aires y sur de entre Ríos, y del que se diferencia por su cuerpo más redondeado y grácil, la cola proporcionalmente más larga y sus orejas más ovaladas y oscuras (Figura 18).

69a. Sin aspecto aterciopelado, con las orejas más redondeadas. .70

70. Tamaño pequeño a mediano; contextura robusta; anillo periocular más o menos evidente según la especie; cabeza ancha y hocico corto; orejas cortas y redondeadas; cola proporcionalmente corta, bicolor y moderadamente peluda, aunque con el escamado dérmico notorio; patas robustas cubiertas por pelitos grises o marrones; la garra del dedo $\mathrm{V}$ de la pata trasera se extiende hasta $1 / 2$ a $1 / 3$ de la falange proximal del dedo IV (Figura 20B); pelos ungueales claros, cubriendo parcialmente las garras; garras de manos y patas largas $y$
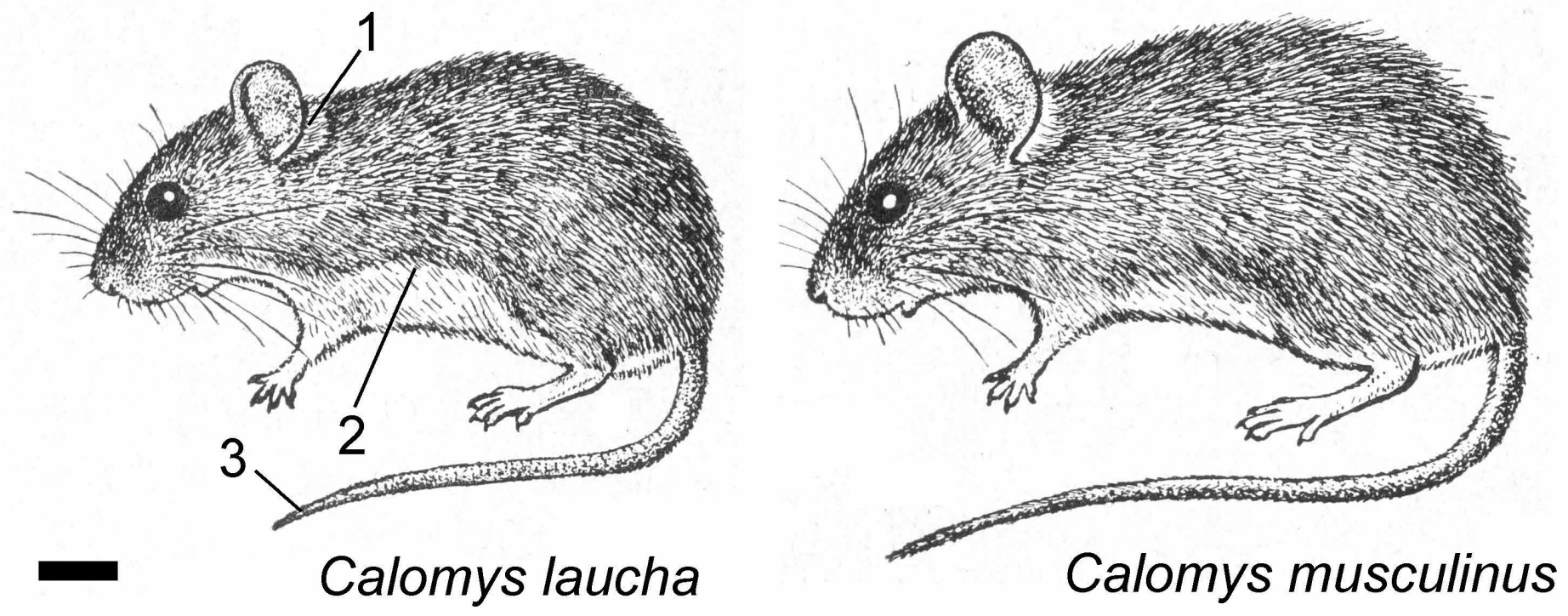

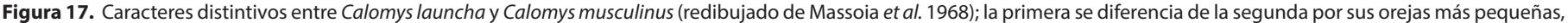

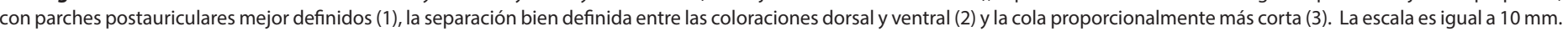



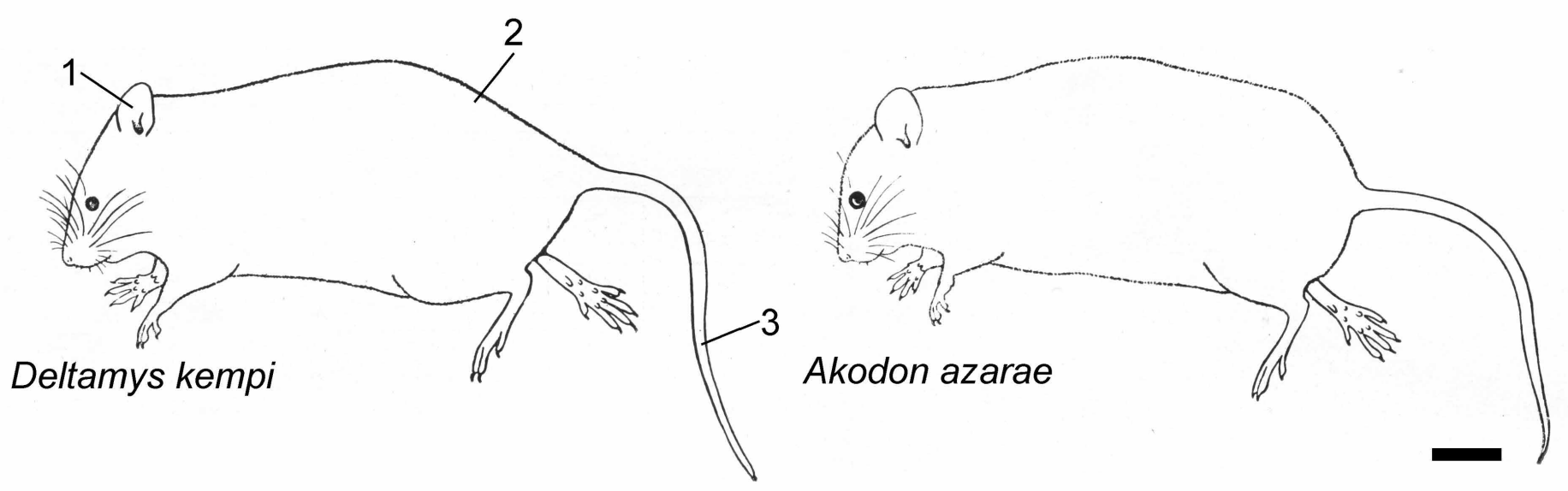

Figura 18. Caracteres distintivos entre Deltamys kempi y Akodon azarae (redibujado de Massoia 1964); el primero se diferencia del segundo por sus orejas más ovaladas (1), su cuerpo más grácil (2) y su cola proporcionalmente más larga (3). La escala es igual a $10 \mathrm{~mm}$.

curvadas, con la garra del dedo III de la mano mayor que el $50 \%$ del largo del mismo dedo y con una quilla corta en la base. .Necromys (Figura 19A-F) 71

70a. La garra del dedo $V$ de la pata trasera se extiende por delante de la primera articulación interfalangeana del dedo IV (Figura 20A). . .75

71. Tamaño pequeño ( $C C=95-103 ; C=63-79 ; P=20-23 ; O$ =12-14); coloración dorsal marrón amarillenta, teñida de ocre hacia los flancos y definiendo una línea que a veces puede estar bien marcada; vientre blancuzco, bien contrastado con el color del dorso; mentón y garganta a veces completamente blancos; anillo periocular amarillento bien marcado; manos y patas cubiertas por pelitos ocre (áreas andinas de altura, por encima de los 3,500 msnm en la provincia de Salta y probablemente de Jujuy) Necromys amoenus (Figura 19C)

71a. Coloración no como en la opción anterior. 72

72. Tamaño mediano ( $C C=98-124 ; C=63-89 ; P=23-29 ; O$ = 11-17); coloración dorsal marrón oscura, con efecto agutí más evidente hacia los flancos; vientre acanelado; mancha blanca en barbilla y/o garganta; con un anillo periocular amarillento bien marcado en algunos especímenes (mayormente restringido a pastizales de altura por encima de las Yungas, entre 1,500 y 3,000 msnm).... Necromys lactens (Figura 19A)

72a. Coloración no como en la opción anterior . .73

73. Tamaño mediano ( $C C=101-120 ; C=53-71 ; P=21-23 ; O$ = 15-16); coloración dorsal castaño oscura brillante a negruzca, con los flancos y mejillas teñidos de ocre o naranja; vientre grisáceo, lavado de amarillo o anaranjado; a veces con una mancha blanca en la barbilla (pastizales y áreas serranas en el sudeste de Buenos Aires)... Necromys obscurus (Figura 19B)

73a. Coloración no como en la opción anterior. . .74

74. Tamaño mediano ( $C C=105-128 ; C=66-96 ; P=20-26$; $\mathrm{O}=13-18)$; coloración dorsal marrón olivácea, con efecto agutí marcado, variablemente lavada de amarillento y más pálida hacia los flancos; vientre grisáceo a blanquecino a gris lavado de ocre; con anillo periocular amarillento y poco marcado (pastizales, pajonales, estepas herbáceas y arbustivas y bordes de campos cultivados; desde el norte de Argentina hasta Buenos Aires y La Pampa). Necromys lasiurus (Figura 19E-F)

74a. Tamaño mediano (CC = 98-113; $C=70-77 ; P=24-26$; $\mathrm{O}=15-17)$; coloración dorsal marrón amarillenta, con efecto agutí marcado; vientre gris, lavado de amarillento y poco diferenciado del dorso; una mancha blanca en el mentón; con anillo periocular amarillento poco marcado; manos y patas cubiertos por pelitos gris claro (pastizales del Chaco serrano en Tucumán)

..Necromys lilloi (Figura 19D)

75. Tamaño pequeño o mediano; vibrisa genal 1 ausente; pelaje largo y suave; coloración dorsal variable, desde muy oscura a marrón grisáceo pálida, usualmente bien diferenciada del vientre, que es más claro; a veces con marcas brillantes rojizas o anaranjadas en hocico, patas y cola; hocico alargado, más perceptible en unas especies (hirta, lanosa, manni) que en otras (andina, illutea, jelski, olivacea); orejas medianas, con o sin parches postauriculares conspicuos; vibrisas abundantes, garras de la mano cortas a moderadamente desarrolladas y sin quilla ventral; dedos de las patas traseras con pelos ungueales largos, que sobrepasan el extremo anterior de las uñas; cola moderadamente peluda y bicolor, con el escamado epidérmico visible o no; 3 o 4 pares de mamas Abrothrix (Figura 13B-F) 76

75a. Tamaño pequeño o mediano; vibrisa genal 1 presente; coloración dorsal y ventral usualmente poco contrastadas (con excepciones, como es el caso de Akodon albiventer), generalmente en tonos grises y marrones; vibrisas cortas e inconspicuas; manos y patas provistos de garras usualmente cortas; cola moderadamente peluda y bicolor, con el escamado epidérmico visible o no; 4 pares de mamas .82

76. Tamaño pequeño $(C C=97-102 ; C=74-79 ; P=24-25$; $\mathrm{O}=18$; coloración muy contrastada; mitad dorsal 


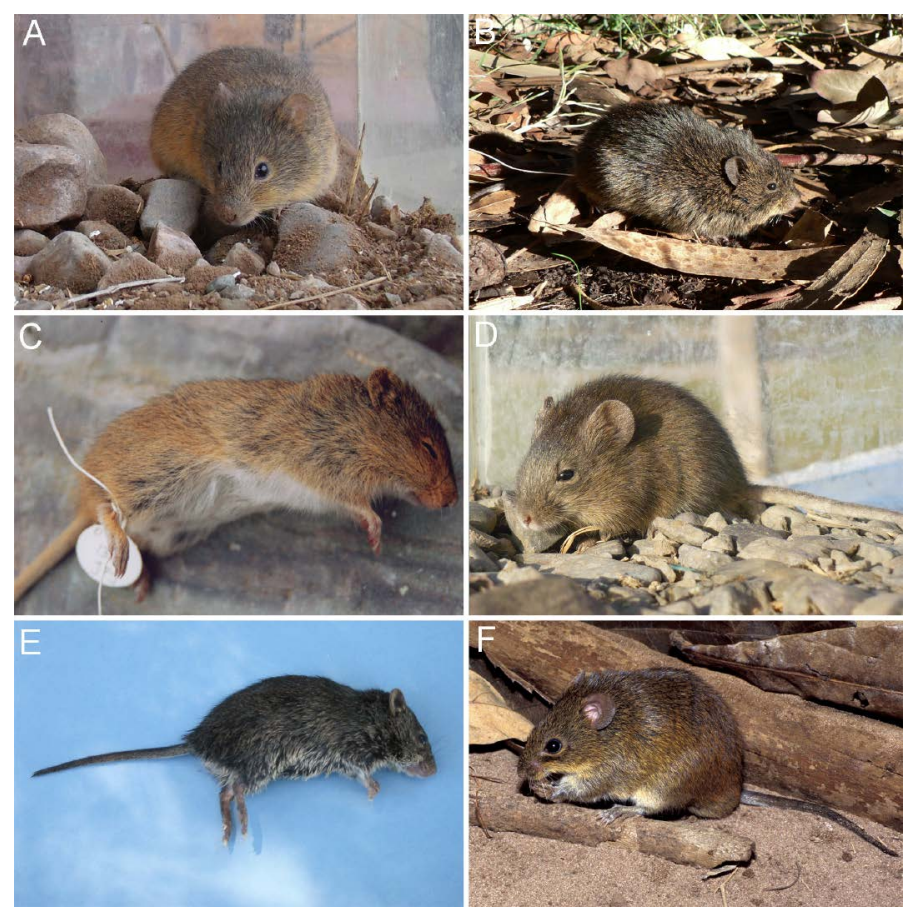

Figura 19. Aspecto externo de Necromys lactens (A), Necromys obscurus (B), Necromys amoenus (C), Necromys lilloi (D) y Necromys lasiurus (E y F). Las fotos no están en escala.

marrón grisácea, netamente separada de la mitad ventral, que es blanca; hocico, orejas, periocular y dorso de las patas y cola rojizo-anaranjado; dedos de la pata blancos; almohadillas palmares y plantares grandes y bulbosas; patas delanteras con garras moderadamente desarrolladas (pastizales y roquedales altoandinos, por encima de 3,400 msnm en Jujuy y Salta)

Abrothrix jelskii (Figura 13B)

76a. Coloración no como en la opción anterior 77

77. Tamaño pequeño ( $C C=110 ; C=72 ; P=24 ; O=15)$; coloración general marrón muy oscuro, casi negro, apenas más claro en el vientre; algunos ejemplares presentan una faja de pelos más rojizos sobre la línea media del dorso (un solo registro en Argentina, en un área boscosa del centro-oeste de Neuquén) .Abrothrix manni

77a. Coloración no como en la opción anterior 78

78. Tamaño mediano ( $C C=110-130 ; C=80-91 ; P=26-30$; $\mathrm{O}=19-22$ ); pelaje dorsal suave, lanoso y denso; coloración general marrón grisáceo oscuro, levemente más clara hacia el vientre; a veces con una mancha blanca en el mentón; la mayoría de los ejemplares presentan el extremo del hocico de color levemente ocráceo; área interna de la oreja cubierta por pelos finos (Bosque Montano y Selva Montana del extremo sur de Yungas entre 700 y 3,000 msnm en el sur de Salta, Catamarca y Tucumán) Abrothrix illutea (Figura 13D)

78a. Coloración, distribución y hábitat no como en la opción anterior

79. Tamaño mediano ( $C C=100-120 ; C=60-84 ; P=22-25 ; O$ =15-18); coloración dorsal marrón grisácea a gris, con una faja de pelos castaño-rojizos hacia la línea media; vientre blanquecino a gris; hocico alargado, manos y patas cubiertos por pelitos blancos a grises (bosques, matorrales y estepas arbustivas y herbáceas desde el sudoeste de Mendoza hasta Tierra del Fuego). ...Abrothrix hirta (Figura 13C)

79a. Coloración no como en la opción anterior, sin faja dorsal castaño rojiza . .80

80. Tamaño pequeño ( $C C=79-111 ; C=51-70 ; P=20-23$; $\mathrm{O}=11-13)$; coloración dorsal olivácea oscura; vientre grisáceo; orejas pequeñas y redondeadas, cubiertas por pelitos ocres; manos y pies cubiertos por pelitos blancos (bosques, matorrales y turberas en Santa Cruz y Tierra del Fuego) Abrothrix lanosa

Nota 19: A. lanosa se diferencia de A. olivacea, con la que convive en el sur de Argentina, por sus orejas más cortas, su coloración dorsal con efecto agutí más marcado, contraste menos notorio entre las tonalidades del dorso y vientre y patas cubiertas por pelitos blancos.

80a. Coloración no como en la opción anterior . .81

81. Tamaño pequeño ( $C C=92-98 ; C=52-65 ; P=20-22 ; O$ = 13-15); coloración general marrón olivácea, a veces lavada de marrón rojizo en el dorso (sobre todo la zona de las ancas) y de gris en los flancos; vientre blanco grisáceo; parches postauriculares blancos; cola marrón en el dorso y blancuzca por debajo (pastizales y arbustales altoandinos (>2,500 msnm), desde Jujuy hasta el centro de Mendoza) Abrothrix andina

81a. Tamaño pequeño ( $C C=70-100 ; C=45-80 ; P=18-22 ; O$ =10-17); coloración dorsal variable, entre gris-oliváceo a marrón oliváceo oscuro; en los ejemplares de áreas forestadas el vientre es de color gris oscuro; en áreas de estepa, los individuos presentan el hocico, el dorso y laterales de la cola y la superficie dorsal de las patas cubiertos por pelitos anaranjados (bosques, matorrales y estepas arbustivas y herbáceas desde el sudoeste de Mendoza hasta Tierra del Fuego) .

...Abrothrix olivacea-A. xanthorhina (Figura 13E-F)

Nota 20: la distinción entre $A$. olivacea, de distribución continental, y A. xanthorhina, restringida a Tierra del Fuego e islas adyacentes, sustentada fundamentalmente en diferencias en el ADN mitocondrial, requiere ser evaluada con el estudio de otros caracteres y el análisis de más especímenes.

82. Tamaño pequeño $(C C=85-105 ; C=70-85 ; P=23-25$; $\mathrm{O}=17-18$ ); pelaje largo y suave; dorsalmente marrón, lavado de anaranjado, más pálido hacia los flancos y poco diferenciado del vientre, que es gris lavado de ocre; área anal y mejillas anaranjadas; orejas medianas, marrón oscuras; manos y patas cubiertas por pelitos marrón oscuro; cola casi desnuda, bicoloreada y con escamado epidérmico notable (selvas en Misiones) ......

.Castoria angustidens (Figura 12A)

Nota 21: Castoria es externamente muy similar a A. montensis y $A$. paranensis, de las que se distingue por sus garras delanteras más cortas y por su coloración general 
más oscura, lavada de anaranjado, especialmente en las mejillas y alrededor del ano.

82a. Coloración no como en la opción anterior, sin manchas anaranjadas en el área anal o mejillas. ..Akodon 83 (Figuras 13A, 20 y 21)

83. Tamaño pequeño $(C C=93-109 ; C=62-77 ; P=20-23 ; O=$ 12-14); pelaje corto y lanoso; dorsalmente marrón grisáceo, con efecto agutí fino; vientre blanco a blanco grisáceo, bien contrastado con el dorso; anillo periocular blanquecino; orejas pequeñas, con parches postauriculares blancos indistintos; manos y patas dorsalmente cubiertos por pelitos blancos; cola peluda y bicolor (pastizales y matorrales altoandinos y de la Puna, por encima de los 2300 msnm, en Jujuy y Salta).

Akodon albiventer (Figura 13A)

83a. Coloración no contrastada como en la opción anterior . .84

84. Tamaño pequeño $(C C=90-114 ; C=60-76 ; P=21-25 ; O=$ 14-16); pelaje denso y suave; coloración dorsal marrón claro, lavada de oliváceo; vientre teñido de ocráceo, moderadamente contrastado con el color del dorso; mentón con un mechón de pelos blancos; cola bicolor (pastizales serranos en Córdoba y San Luis por encima de 1,500 msnm). Akodon polopi (Figura 20F)

84a. Distribución no como en la opción anterior (excepto por $A$. dolores, de la que se diferencia por su menor tamaño) 85

85. Tamaño pequeño $(C C=75-114 ; C=68-90 ; P=21-25 ; O=$ 14-17); dorso marrón oscuro a marrón oliváceo, lavado de amarillento hacia los flancos y mejillas, con efecto agutí poco evidente; vientre gris a gris pardusco, a veces lavado de amarillento; orejas marrones; cola bicolor, con anillos poco marcados; patas dorsalmente cubiertas por pelitos castaños y grisáceos (pastizales, pajonales, bordes de campos cultivados y estepas arbustivas; también en baldíos, basurales, bordes de arroyos y terraplenes de ferrocarril en áreas urbanas y suburbanas, desde Formosa y Corrientes hasta La Pampa y Buenos Aires) ..........Akodon azarae (Figura 20G) [Nota 22: A. azarae es simpátrica con A. dolores y A. toba, de las que se diferencia por su menor tamaño; se distingue de A. iniscatus por su cola y patas proporcionalmente más largas y su coloración menos grisácea].

85a. Coloración, medidas y/o distribución no como en la opción anterior . .86

86. Mayormente en ambientes áridos a semiáridos del Chaco Seco, Monte y Patagonia .

86a. Distribución no como en la opción anterior 89

87. Tamaño pequeño ( $C C=80-110 ; C=50-80 ; P=17-23 ; 0$ = 11-14); coloración dorsal marrón olivácea uniforme, con efecto agutí fino; vientre gris y moderadamente demarcado del dorso; un mechón de pelos blancos en el mentón; cola bien cubierta de pelos y bicolor (pastizales, estepas arbustivas y herbáceas del Monte y Patagonia, desde La Pampa y sudoeste de Buenos Aires hasta Santa Cruz) ..............................Akodon iniscatus

Nota 23: A. iniscatus es ampliamente simpátrido con $A$. dolores en el centro-sur de Argentina, del que se diferencia por su tamaño más pequeño y orejas más cortas.

87a. Tamaño mediano, orejas $>16 \mathrm{~mm}$ . .88

88. Tamaño mediano ( $C C=100-120 ; C=78-89 ; \mathrm{P}=22-24 ; \mathrm{O}=$ 16-19); pelaje largo y denso; coloración dorsal marrón olivácea pálida a gris olivácea, lavado de amarillo; vientre blanco grisáceo, moderadamente contrastado con el dorso, pero sin línea de separación definida; anillo periocular pálido; orejas marrones; manos y patas cubiertos por pelitos blanco grisáceos; cola bicolor y bien cubierta de pelos (pastizales, pajonales, estepas arbustivas y bosques xerófilos en el Espinal, Chaco Seco (en el NOA) y Monte, desde Tucumán y Santiago del Estero, por el oeste, hasta el sur de Buenos Aires y noroeste de Chubut) .............. Akodon dolores (Figura 21B)

Nota 24: $A$. dolores es simpatrida con $A$. azarae y $A$. iniscatus en una zona amplia del centro y centro-sur de Argentina, de las que se diferencia por su mayor tamaño; evidencias cariotípicas, moleculares y morfológicas sugieren su conespecificidad con $A$. toba.

88a. Tamaño mediano ( $C C=91-126 ; C=67-87 ; P=24-27 ; O$ = 16-20); coloración dorsal marrón olivácea, lavada de gris, con efecto agutí fino; vientre gris, escarchado de blanco, moderadamente contrastado con el dorso; anillo periocular poco marcado; en algunos especímenes hay una mancha blanca poco conspicua en el mentón; manos y patas cubiertos por pelitos blanco grisáceos;

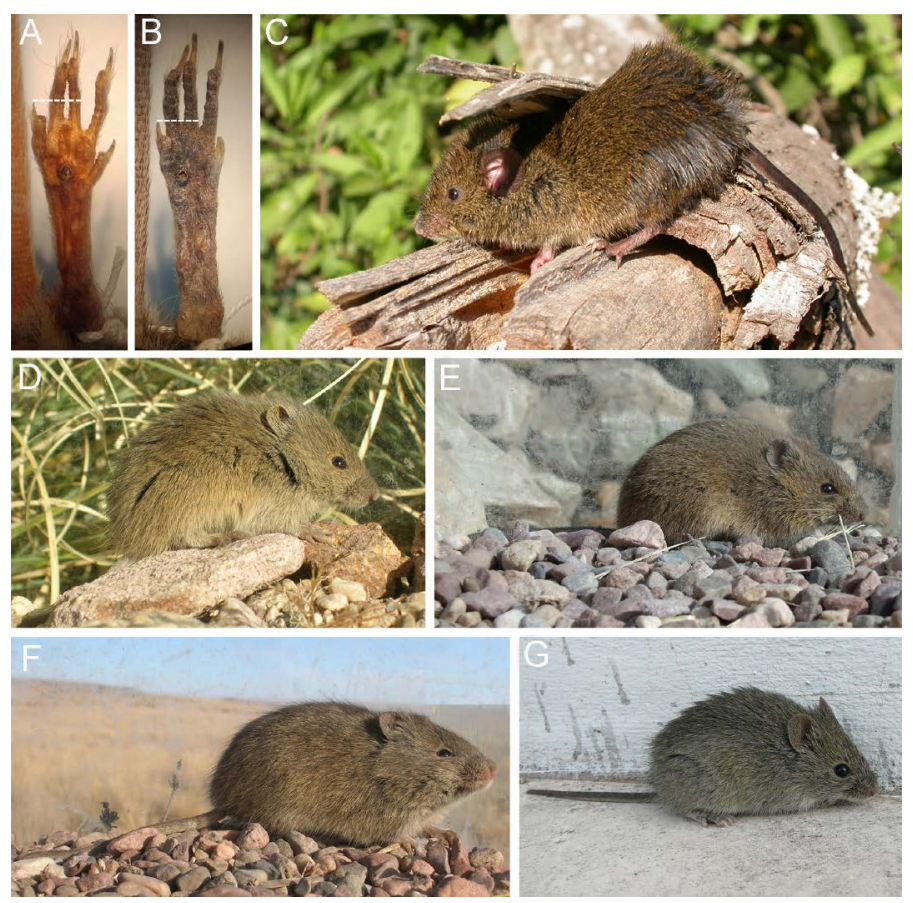

Figura 20. Vistas plantares de las patas traseras de Akodon azarae (A) y Necromys lasiurus (B) (compárese la longitud del dedo $\mathrm{V}$ con respecto al IV) y aspecto externo de Akodon fumeus (C), Akodon spegazzini (D), Akodon boliviensis (E), Akodon polopi (F) y Akodon azarae (G). Las fotos no están en escala. 
cola bicolor y bien cubierta de pelos (pastizales, pajonales y matorrales en el Chaco Seco, desde Salta y Formosa hasta Santiago del Estero) .Akodon toba (Figura 21A)

Nota 25: $A$. toba se diferencia de $A$. simulator por su pelaje con efecto agutí más fino y por la ausencia de tonalidades dorsales castaño amarillentas a rojizas (especialmente hacia las ancas) y de A. azarae por su mayor tamaño; $A$. montensis posee el vientre con tonos castaños o grisáceo amarillentos.

89. Nordeste de Argentina (Corrientes, Misiones, este de Chaco y Formosa) .90

89a. Noroeste y oeste de Argentina (desde Jujuy y Salta, por el oeste, hasta Mendoza) . .91

90. Tamaño pequeño $(C C=70-109 ; C=47-69 ; P=17-19$; $0=11-12$ ); coloración dorsal marrón grisácea oscura, con efecto agutí fino; vientre gris, poco diferenciado del dorso; manos y patas cubiertos por pelitos blancos; cola cubierta por pelitos marrones, pero con escamado epidérmico igualmente visible (pastizales en el sur de Misiones) Akodon philipmyersi

90a. Tamaño mediano ( $C C=88-125 ; C=60-98 ; P=22-25$; 0 = 15-19); coloración dorsal marrón olivácea, poco contrastada con el vientre, que es de color castaño o gris amarillento; manos y patas cubiertos por pelos marrón grisáceos; pelos ungueales blancos y largos, que se extienden por delante de las uñas; cola bicolor, con el escamado dérmico claramente visible ( $A$. montensis ocupa selvas y bosques en galería en Misiones, norte de Corrientes y este de Chaco y Formosa, mientras que $A$. paranaensis tiene un solo registro para un área forestada en el centro-norte de Misiones)

Akodon montensis-A. paranaensis (Figura 21D)

Nota 26: A. montensis y A. paranaensis se diferencian mayormente por rasgos cariotípicos y morfométricos; $A$. montensis se diferencia de $A$. toba, con la que coexiste en el este de Chaco y Formosa, por su coloración ventral castaña o gris amarillenta (blanco grisáceo en A. toba).

91. Tamaño pequeño a mediano ( $C C=83-114 ; C=65-89 ; \mathrm{P}$ = 21-27; $O=14-21)$; coloración dorsal marrón olivácea, finamente salpicada de negro y generalmente poco contrastada con el vientre; orejas del mismo color que el dorso; anillo periocular ausente o poco definido; mancha blanca en el mentón poco definida; cola apenas bicoloreada (yungas y pastizales de altura en el sudeste de Jujuy (Sierra de Santa Bárbara y áreas adyacentes), entre 700 y 2,500 msnm) Akodon sylvanus

91a. Coloración y medidas distintos de la opción anterior .... . .92

92. Longitud CC generalmente $>100 \mathrm{~mm}$ . .93

92a. Longitud CC generalmente $<100 \mathrm{~mm}$ . .94

Nota 27: la separación entre un grupo de especies con longitudes de CC mayores o menores de $100 \mathrm{~mm}$ es orientativa; frente a esta disyuntiva, lo más conveniente es que el usuario de la clave evalúe alternativamente las distintas opciones. Muchas de las especies de Akodon en el NOA son difíciles de distinguir externamente entre sí, requiriendo de otras evidencias (cráneos, secuencias de ADN), para una identificación precisa.

93. Tamaño mediano ( $C C=93-126 ; C=52-99 ; \mathrm{P}=22-29 ; \mathrm{O}$ = 12-22); dorso marrón oliváceo, finamente salpicado con pelos negros; vientre levemente más pálido, con una mancha de pelos blancos en el mentón y a veces la garganta; cola bicolor (pisos superiores de las Yungas en Jujuy y Salta, entre 1,000 y 3,000 msnm)

Akodon budini

93a. Tamaño mediano (CC = 92-135; C = 59-105; P = 20-29; $\mathrm{O}=15-22)$; coloración dorsal marrón grisácea, lavada de amarillo o rojizo (especialmente en la grupa), más o menos oscura o pálida según los individuos o las poblaciones; flancos y vientre gris blanquecinos, a veces lavados de ocre, bien delimitados del color del dorso; anillo periocular amarillento evidente; mancha blanca en el mentón y garganta de desarrollo variable, pero siempre presente; cola bicolor; patas y manos cubiertas por pelitos blanquecinos (ambientes forestados en las Yungas $y$ en el ecotono con pastizales de altura y con ambientes chaqueños, desde Jujuy hasta La Rioja y Santiago del Estero) ............ Akodon simulator (Figura 21C)

Nota 28: $A$. simulator se diferencia de $A$. toba por su pelaje con efecto agutí más marcado y la grupa más rojiza.

94. Tamaño pequeño a mediano $(C C=63-117 ; C=70-90$; $\mathrm{P}=20-26 ; \mathrm{O}=12-19) ;$ pelaje dorsal marrón oliváceo oscuro, a veces con tonos rojizos, más pálido hacia el vientre; anillo periocular pálido; cola escasamente peluda y bicolor; patas cubiertas por pelitos bicoloreados, blancos y marrones (bosques de Yungas en Salta y Jujuy) ......................................Akodon fumeus (Figura 20C)

94a. Coloración no como en la opción anterior; patas cubiertas por pelitos completamente blanquecinos ....

95. Tamaño pequeño $(C C=85-101 ; C=48-87 ; P=20-25 ; O$ =11-16); coloración dorsal marrón rojiza (estepas arbustivas y pastizales en San Juan y Mendoza)

Akodon oenos

95a. Desde La Rioja hacia el norte 96

96. Tamaño pequeño $(C C=86-103 ; C=57-83 ; P=18-23 ; O=$ 13-15); dorso y flancos marrón oliváceos; vientre más pálido, lavado de ocre; área inguinal más oscura, a veces rojiza; anillo periocular amarillento; cola bicolor y bien cubierta de pelos (pastizales de altura de Yungas, Altoandinos y de la Puna por encima de los 2500 msnm en Jujuy y Salta) ... Akodon boliviensis (Figura 20E)

96a. Coloración no como en la opción anterior .97

97. Tamaño pequeño $(C C=78-94 ; C=46-75 ; P=20-26$; $O$ =12-15); coloración dorsal variable, que oscila entre 

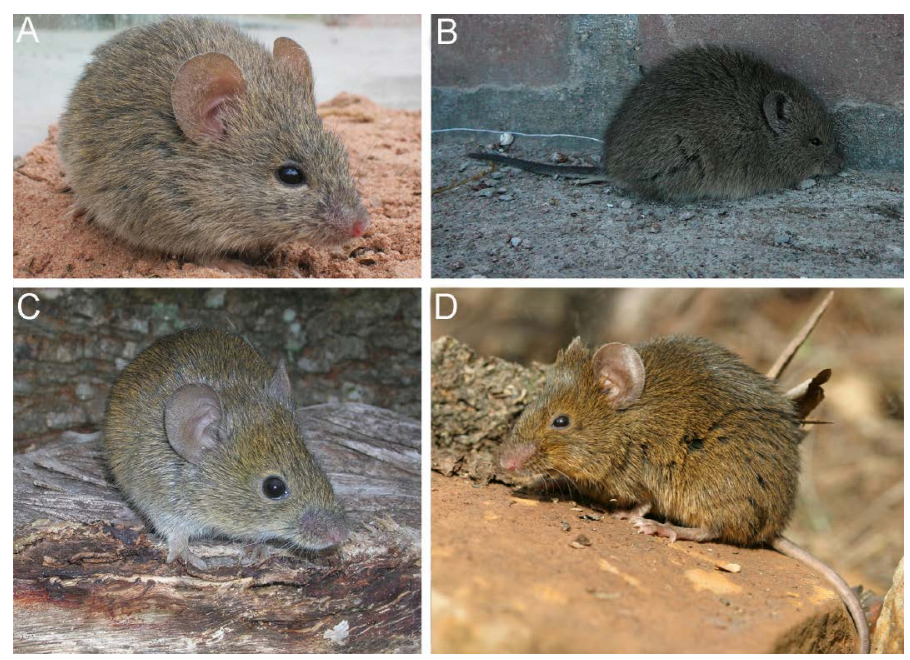

Figura 21. Aspecto externo de Akodon toba (A), Akodon dolores (B), Akodon simulator (C) y Akodon montensis (D). Las fotos no están en escala.

el marrón amarillento, marrón rojizo o marrón oliváceo; vientre gris blanquecino, gris amarillento o canela, bien contrastado con el dorso; a veces con unos pocos pelos blancos en el mentón, pero sin formar un parche conspicuo; cola fuertemente bicolor (yungas y pastizales de altura, entre 400 y 3,500 msnm, en Jujuy, Salta, Tucumán y Catamarca). Akodon caenosus

97a. Tamaño pequeño a mediano (CC $=68-120 ; C=45-84$; $\mathrm{P}=17-25 ; \mathrm{O}=10-21)$; coloración similar a $A$. caenosus, de la que se diferencia por su tamaño algo mayor. (Yungas y pastizales de altura, entre 400 y 3,500 msnm, desde el centro de Salta hasta La Rioja) Akodon spegazzini (Figura 20D)

\section{Clave C. Familia Muridae}

1. Tamaño pequeño $(C C=74-98 ; C=69-89 ; P=16-24 ; O$ = 11-19); longitud CC $<100 \mathrm{~mm}$ pelaje muy corto, suave y lustroso; dorsalmente variable, entre gris claro y marrón, más pálido hacia el vientre; cola de longitud mayor que la longitud conjunta de la cabeza más el cuerpo; orejas grandes, casi desnudas y membranosas; patas estrechas; 5 pares de mamas. En todo el país, mayormente peridoméstica, pero también en áreas naturales Mus musculus (Figura 22B)

1a. Tamaño grande; longitud CC $>150 \mathrm{~mm}$. Rattus 2

2. Tamaño grande ( $C C=150-270 ; C=105-240 ; P=30-44$; $\mathrm{O}=14-22$; cuerpo robusto y hocico obtuso; pelaje híspido, dorsalmente marrón amarillento o grisáceo, con el vientre marrón grisáceo claro o gris; cola con anillos marcados, apenas más corta que la longitud conjunta de la cabeza más el cuerpo; orejas pequeñas y redondeadas, casi desnudas, que dobladas hacia adelante no alcanzan el borde posterior del ojo; ojos pequeños; 6 pares de mamas. En todo el país, mayormente peridoméstica, pero también en áreas naturales. 2a. Tamaño grande $(C C=157-184 ; C=163-229 ; P=31-38 ; O$ = 20-26); cuerpo alargado y hocico proporcionalmente aguzado; se reconocen tres variantes de coloración: a) dorsalmente gris plomizo oscuro, con el vientre gris claro; b) dorso marrón amarillento, más claro hacia el vientre; c) dorso gris perla, con el vientre blanco puro; cola con anillos marcados, apenas más larga que la longitud conjunta de la cabeza más el cuerpo; orejas grandes, ovaladas y casi desnudas, que dobladas hacia delante alcanzan el borde posterior del ojo; ojos grandes; 5 a 6 pares de mamas. En todo el país, mayormente peridoméstica, pero también en áreas naturales

Rattus rattus (Figura 22D)

\section{Discusión}

Las claves para la identificación de especies son una herramienta útil para la investigación biológica en general. En muchas ocasiones, constituyen el punto de partida para el entrenamiento de investigadores que desean conocer la diversidad de los grupos taxonómicos que constituyen el foco de su interés. En otras instancias, las claves son un insumo imprescindible para llevar a cabo estudios en terreno, incluyendo inventarios y monitoreos de biodiversidad (Bonvicino et al. 2008; Godínez y Guerrero 2014). En algunos casos, como en el de los roedores muroideos, la necesidad de contar con claves de identificación tiene un sentido particularmente destacado. Este grupo normalmente constituye la mayor fracción de la diversidad de los ensambles locales de mamíferos, lo cual impone un reto a la hora de individualizar sus especies. Pero más importante aún, esta diversidad tiene un correlato directo con múltiples funciones ecosistémicas, e impactos económicos (muchas especies constituyen plagas de cultivos) y sanitarios (algunas son vectores de enfermedades zoonóticas potencialmente letales para el hombre), destacando la relevancia que tiene la identificación taxonómica precisa de sus

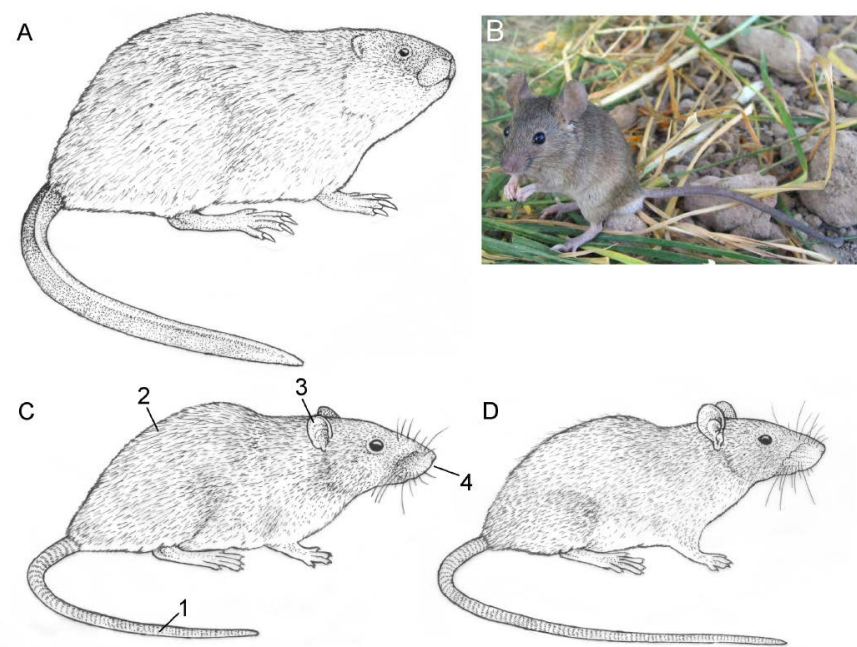

Figura 22. Aspecto externo de Ondatra zibethicus (A), Mus musculus (B), Rattus nor vegicus (C) y Rattus rattus (D). En C y D se destacan los caracteres distintivos entre ambas especies de Rattus; en R. norvegicus la cola (1) es más corta que la longitud conjunta de la cabeza más el cuerpo (vs. más larga en $R$. rattus), el cuerpo (2) más compacto (vs. más estilizado), las orejas (3) más cortas (vs. más largas) y el hocico más corto (vs. más puntiagudo). 
especies en las investigaciones (Patton et al. 2015 y la literatura allí anotada).

La mayoría de las claves elaboradas para roedores incluyen caracteres de la morfología externa y cráneo-dentaria (e. g., Massoia y Fornes 1967a,1969; Patton et al. 2015). Sin embargo, muchos estudios deben realizarse en el campo en circunstancias de investigación o manejo en las cuales la colecta de ejemplares no es una opción viable y por lo tanto no se accede a material óseo. En este sentido, creemos que las claves basadas en caracteres externos constituyen un primer paso hacia la solución de este problema. La similitud en el plan morfológico general entre las especies de roedores muroideos constituyó un reto importante a la hora de elaborar las claves. A pesar de estas limitaciones, nuestra experiencia en el manejo de las claves y su puesta a prueba con personas no entrenadas en la determinación de roedores, indica que la identificación de la gran mayoría de los taxones tratados no presenta grandes inconvenientes.

$\mathrm{Si}$ bien existen algunos antecedentes generales (Yepes 1935 b; Olrog y Lucero 1981) y regionales (e. g., Barquez et al. 1991; Díaz y Barquez 2002; Gómez Villafañe et al. 2005; Chebez et al. 2014) de contribuciones elaboradas para la identificación de roedores a partir de caracteres externos, ninguno de esos trabajos fue diseñado con el formato de una clave dicotómica y con el alcance taxonómico y geográfico que aquí se propone. Las claves elaboradas por Massoia y Fornes $(1967 a, 1969)$ son destacables por el especial cuidado que el autor puso en la descripción de los caracteres externos de los muroideos, correspondiéndole el crédito de haber diferenciado taxones externamente muy similares, cuyas diferencias habían pasado desapercibidas para otros investigadores (e. g., Calomys, véase Hershkovitz 1962 y Massoia et al. 1968). Sin embargo, sus claves fueron pensadas con un alcance regional y elaboradas sobre un esquema taxonómico que con el tiempo ha quedado desactualizado.

Aunque creemos que las claves presentadas en este trabajo constituirán una ayuda para la identificación de la mayoría de las especies de muroideos de Argentina, las mismas no pretenden reemplazar a otras herramientas y aproximaciones que también son necesarias en el proceso de identificación. Antes bien, su objetivo es el de ser una guía con la cual disminuir el margen de error en las identificaciones, tarea de por sí poco sencilla y que debe complementarse con otras evidencias. Si bien muchos taxones poseen características lo suficientemente distintivas para una identificación certera, sea a nivel genérico (e. g., los tubérculos interdigitales fusionados en Eligmodontia, las patas traseras con membranas interdigitales en Holochilus, Nectomys o Pseudoryzomys) o específico (e. g., el pelaje espinoso de Abrawayaomys ruschi), muchos otros (e. g., las especies de Akodon, Calomys, Oligoryzomys) son ciertamente difíciles de identificar si no se tiene cierta experiencia de campo, un conocimiento básico sobre las distribuciones geográficas y preferencias de hábitat, o se cuenta con la ayuda de otras fuentes de evidencias (e. g., cráneos, cariotipos, secuencias de ADN). Aun así, ninguna identificación está exenta de errores o de la posibilidad de ser corregida sobre la base de nuevas evidencias. Del mismo modo, siempre existe la posibilidad de encontrarse con ejemplares que se aparten de las características generales de su especie (e. g., individuos muy viejos o con alteraciones de color) o incluso de hallar especies nuevas para la ciencia o previamente no citadas para Argentina.

Para algunos taxones, los datos de distribución y ambientes que se ofrecen en las claves pueden facilitar la identificación. Por ejemplo, Akodon spegazzini y A. oenos son externamente muy similares, pero sus distribuciones aparentemente no se solapan (Jayat et al. 2020). Lo mismo sucede entre A. boliviensis y A. spegazzini (Jayat et al. 2010) o Geoxus michaelseni y G. valdivianus (Teta y D'Elía 2017). El hábitat también puede ser orientativo, tal es el caso de algunas especies del género Phyllotis que están muy vinculadas a la presencia de afloramientos rocosos (Pearson 1958). Aun así, tanto la distribución como el hábitat deben ser cuidadosamente sopesados, pues nuestro conocimiento sobre estos aspectos es aún incompleto y no es infrecuente encontrar especies fuera de su área de distribución conocida o en ambientes novedosos (e. g., Jayat et al. 2018).

En última instancia, debe entenderse que toda determinación realizada mediante estas claves debe considerarse como tentativa, sujeta al estudio de otros conjuntos de caracteres y la revisión de la literatura. Mas en general, se sugiere estar siempre en contacto con especialistas y coleccionar, en todos los casos en los que sea posible, ejemplares de referencia para resolver los interrogantes que puedan plantearse durante el proceso de identificación. Por ejemplo, en los estudios ecológicos que requieran de la captura y recaptura de ejemplares, se deberían establecer algunas líneas de trampas por separado que permitan la colección de especímenes completos para su posterior estudio (Pearson 1995). En este sentido, debe quedar claro que la colección de ejemplares y su depósito en colecciones biológicas resulta una actividad irremplazable y el único camino para obtener determinaciones sólidas y repetibles en el tiempo (Patterson 2002).

Nota final. Por todo lo expresado previamente, resulta evidente que un trabajo como el que aquí se propone es factible de ser perfeccionado, ya sea a partir de nuevos estudios o por la experiencia de otros investigadores con la identificación de especies. Por este motivo, invitamos a todos aquellos que estén interesados a contactarse con los autores para señalar potenciales errores y/o sugerir modificaciones, en un esfuerzo por mejorar colectivamente la utilidad de esta clave como herramienta.

\section{Agradecimientos}

Muchos de los datos vertidos en estas claves han sido acumulados durante trabajos de campo realizados en las últimas dos décadas y discutidos a lo largo de los años con colegas y colaboradores, en el campo y gabinete. Aun cuando involuntariamente podamos omitir algunos nombres, 
hacemos llegar nuestra gratitud a A. Andrade, D. Bilenca, R. Cavia, S. Cirignoli, J. Contreras, G. Cueto, G. D'Elía, A. Formoso, N. Fracassi, C. Galliari, I. Gómez-Villafañe, C. Hercolini, I. Tomasco, C. Lanzone, E. Lessa, G. S. Libardi, E. Muschetto, A. Novillo, U. Pardiñas, J. Pereira, A. Ochoa, A. Ojeda, R. Ojeda, P. Ortiz, D. Podestá, O. Suarez, M. Tammone, J. Torres, D. Udrizar Sauthier y L. Valdez. La realización de estas claves no hubiese sido posible sin la generosidad de los siguientes grupos de trabajo y personas, que aportaron fotografías para la ilustración de las mismas: Biodiversidad desde el Sur (Figuras 5D, Figura 6E-F), Pedro Blendinguer (Figura 20C), Gerardo Cueto (Figura 22B), Ignacio Ferro (Figuras 4E, 13D), Carlos Galliari (Figuras 3A, 9C-D, 12C, 16D), Andrés Johnson (Figuras 7A, 8B, 16A y E, 21D), Agustina Novillo (Figura 4B), Emanuelle Passa (Figuras 3B, 7B), Felipe Peters (Figura 12A), Darío Podestá (Figuras 4A, 8C, 13G-H), Rosario Robles (19B), Paulo Ricardo Roth (Figuras 3D-E; 5C, 7C, 9B, 12D, 19F) e Ivanna Tomasco (Figuras 10F, 13E). Dos evaluadores anónimos proveyeron comentarios que contribuyeron a mejorar esta publicación.

\section{Literatura citada}

Abreu, E. F., D. M. Henriques Jung, A. Uarth Christoff, V. H. Valiatı, S. A. Jansa, y A. R. Percequillo. 2021. Systematics of Brucepattersonius Hershkovitz, 1998 (Rodentia, Sigmodontinae): molecular species delimitation and morphological analyses suggest an overestimation in species diversity. Systematics and Biodiversity. https://doi.org/10. 1080/14772000.2021.1890270

Barquez, R. M., M. A. Mares, y R. A. Ojeda. 1991. Mamíferos de Tucumán. Oklahoma Museum of Natural History. University of Oklahoma. Norman, EE.UU.

Bonvicino, C. R., J. A. de Oliveira, y P. S. D'Andrea. 2008. Guía dos roedores de Brasil. Com chaves para gêneros baseadas em caracteres externos. Centro Pan-Americano de Febre Aftosa - OPAS/OMS. Rio de Janeiro, Brasil.

Carrizo, L. V., M. J. Tulli, D. A. Dos Santos, y V. Abdala. 2014. Interplay between postcranial morphology and locomotor types in Neotropical sigmodontine rodents. Journal of Anatomy 224:469-481.

Chebez, J. C., U. F. P. Pardiñas, y P. Teta. 2014. Mamíferos Terrestres de Patagonia, Sur de Argentina y Chile. Vázquez Mazzini Editores. Buenos Aires, Argentina.

Díaz, M. M., y R. M. Barquez. 2002. Los mamíferos de Jujuy, Argentina. Literature of Latin America. Buenos Aires, Argentina.

Gyldenstolpe, N. 1932. A manual of Neotropical sigmodont rodents. Kunglia Svenska Vetenskapsakademiens Handlingar, Stockholm (ser. 3) 11:1-164.

Godinez, E. G., y S. Guerrero. 2014. Los roedores de Jalisco, México: clave de determinación. Therya 5:633-678.

Gómez Villafañe, I., M. Miño, R. Cavia, K. Hodara, P. Courtalón, O. V. SuÁrez, y M. Busch. 2005. Roedores. Guía de la provincia de Buenos Aires. Literature of Latin America. Buenos Aires, Argentina.

Hershkovitz, P. 1962. Evolution of Neotropical cricetine rodents (Muridae) with special reference to the phyllotine group. Fieldiana Zoology 46:1-524.
Jayat, J. P., P. E. Ortiz, G. D’Elía, P. Teta, y F. R. González. 2018. Nuevos registros de distribución geográfica para diez especies de sigmodontinos (Rodentia: Cricetidae) del noroeste argentino. Revista del Museo Argentino de Ciencias Natrales, nueva serie 20:165-177.

Jayat, J. P., P. E. Ortiz, A. Ojeda, A. Novillo, P. Teta, G. D'Elía, y R. A. OJedA. 2020. Morphometric data suggest that Akodon oenos (Rodentia, Cricetidae, Sigmodontinae) is not a junior synonym of $A$. spegazzinii. Mammalia 84:299-313.

Jayat, J. P., P. E. Ortiz, J. Salazar-Bravo, U. F. J. Pardiñas, Y G. D'Elía. 2010. The Akodon boliviensis species group (Rodentia: Cricetidae: Sigmodontinae) in Argentina: species limits and distribution, with the description of a new entity. Zootaxa 2409:1-61.

Lacher, T. E., W. J. Murphy, J. Rogan, A. T. Smith, y N. S. UpHAM. 2017. Evolution, phylogeny, ecology, and conservation of the Clade Glires: Lagomorpha and Rodentia. Handbook of mammals of the world, Volume 6: lagomorphs and rodents (D. E. Wilson, J. T. E. Lacher y R. A. Mittermeier, eds.). Lynx Ediciones. Barcelona, España.

Maestri, R., B. D. Patterson, R. Fornel, L. R. Monteiro, y T. R. O. De Freitas. 2016. Diet, bite force and skull morphology in the generalist rodent morphotype. Journal of Evolutionary Biology 29:2191-2204.

Mares, M. A., J. K. Braun, B. S. Coyner, y R. A. Van Den Bussche. 2008. Phylogenetic and biogeographic relationships of gerbil mice Eligmodontia (Rodentia, Cricetidae) in South America, with a description of a new species. Zootaxa 1753:1-33.

Massoia, E. 1964. Sistemática, distribución geográfica y rasgos etoecológicos de Akodon (Deltamys) kempi (Rodentia, Cricetidae). Physis 24:299-305.

Massoia, E. 1969. Caracteres comunes y distintivos de Oxymycterus nasutus (Waterhouse) y Oxymycterus iheringi Thomas (Rodentia, Cricetidae). Physis 28:315-321.

Massoia, E. 1971. Akodon varius toba Thomas en la Rep. Argentina (Mammalia - Rodentia - Cricetidae). Revista de Investigaciones Agropecuarias, INTA, Serie 4, Patología Animal 5:123-129.

Massoia, E. 1973a. Descripción de Oryzomys fornesi, nueva especie y nuevos datos sobre especies y subespecies argentinas del subgénero Oryzomys (Oligoryzomys) (Mammalia, Rodentia, Cricetidae). Revista de Investigaciones Agropecuarias, INTA, Serie 1, Biología y Producción Animal 10:21-37.

Massoia, E. 1973b. Presencia y rasgos bioecológicos de Oryzomys longicaudatus pampanus, nueva subespecie en la provincia de Buenos Aires (Mammalia, Rodentia, Cricetidae). Revista de Investigaciones Agropecuarias, INTA, Serie 1, Biología y Producción Animal 10:43-49.

Massoia, E. 1974. Datos sobre un cricétido nuevo para la Argentina: Oryzomys (Oryzomys) capito intermedius y sus diferencias con Oryzomys (Oryzomys) legatus (Mammalia, Rodentia). Revista de Investigaciones Agropecuarias, INTA, Serie 5, Patología Vegetal 11:1-7.

Massoia, E. 1976. Mammalia. Fauna de agua dulce de la República Argentina (R. Ringuelet, dir.). FECIC. Buenos Aires, Argentina. 
MAssoiA, E. 1979. Descripción de un género y especie nuevos: Bibimys torresi (Mammalia - Rodentia - Cricetidae - Sigmodontinae - Scapteromyini). Physis, Sección C, 38:1-7.

Massoia, E., y A. Fornes. 1964. Notas sobre el género Scapteromys (Rodentia, Cricetidae). I. Sistemática, distribución geográfica y rasgos etoecológicos de Scapteromys tumidus (Waterhouse). Physis 24:279-297.

Massoia, E., Y A. Fornes. 1965a. Oryzomys (Oecomys) Thomas,1906, nuevo subgénero de cricétidos para la República Argentina (Rodentia). Physis 25:319-324.

Massoia, E., y A. Fornes. 1965b. Contribución al conocimiento de los roedores miomorfos argentinos vinculados con la Fiebre Hemorrágica (Rodentia: Cricetidae y Muridae). Comisión Nacional Coordinadora para el Estudio y Lucha contra la Fiebre Hemorrágica Argentina, Ministerio de Asistencia Social y Salud Pública. Buenos Aires, Argentina.

MAssoiA, E., y A. Fornes. 1967a. Roedores recolectados en la Capital Federal (Caviidae, Cricetidae, Muridae). INTA, IDIA 240:47-53.

MAssola, E., Y A. Fornes. 1967b. El estado sistemático, distribución geográfica y datos etoecológicos de algunos mamíferos neotropicales (Marsupialia y Rodentia) con la descripción de Cabreramys, género nuevo (Cricetidae). Acta Zoológica Lilloana 23:407-430.

MAssolA, E., Y A. Fornes. 1969. Claves para el reconocimiento de los roedores del Delta del Paraná. INTA, IDIA 243:11-18.

Massoia, E., A. Fornes, R. Wainberg, y T. G. Fronza. 1968. Nuevos aportes al conocimiento de las especies bonaerenses del género Calomys (Rodentia, Cricetidae). Revista de Investigaciones Agropecuarias, INTA, Serie 1, Biología y Producción Animal 5:63-92.

Myers, P. 1989. A preliminary revision of the varius group of Akodon (A. dayi, dolores, molinae, neocenus, simulator, toba and varius). Advances in Neotropical Mammalogy (K.H. Redford y J.F. Eisenberg, eds.). Sandhill Crane Press. Gainesville, USA.

Olrog, C. C., y M. M. Lucero. 1981. Guía de los mamíferos argentinos. Fundación Miguel Lillo. Tucumán, Argentina.

Pacheco, V. 2003. Phylogenetic analyses of the Thomasomyini (Muroidea: Sigmodontinae) based on morphological data. Tesis de Doctorado. City University, New York.

Pardiñas, U. F. J., P. Teta, y J. Salazar-Bravo. 2015. A new tribe of Sigmodontinae rodents (Cricetidae). Mastozoología Neotropical 22:171-186.

Pardiñas, U. F. J., P. Myers, L. León-Paniagua, N. Ordóñez Garza, J. Cook, B. Kryštufek, R. Haslauer, R. Bradley, G. Shenbrot, y J. L. Patton. 2107. Family Cricetidae. Handbook of the Mammals of the World - Volume 7, Rodents II (D. E. Wilson, R. A. Mittermeier y T. E. Lacher, eds.). Lynx Edicions. Barcelona, España.

Patterson, B. D. 2002. On the continuing need for scientific collecting of mammals. Mastozoología Neotropical 9:253-262.

Patton, J. L., U. F. J. Pardiñas, y G. D’Elia (eds.). 2015. Mammals of South America, Vol. 2: Rodents. University of Chicago Press. Chicago, EE.UU.

Pearson, O. P. 1958. A taxonomic revision of the rodent genus Phyllotis. University of California, Publications in Zoology 56:391-496.
Pearson, O. P. 1995. Annotated keys for identifying small mammals living in or near Nahuel Huapi National Park or Lanin National Park, southern Argentina. Mastozoología Neotropical 2:99-148.

Rodrigues do Prado, J., L. L. Knowles, y A. R. Percequillo. 2021. New species boundaries and the diversification history of marsh rat taxa clarify historical connections among ecologically and geographically distinct wetlands of South America. Molecular Phylogenetics and Evolution 155:106992.

Salazar-Bravo, J., U. F. J. Pardiñas, H. Zeballos, y P. Teta. 2016. Description of a new tribe of sigmodontine rodents (Cricetidae: Sigmodontinae) with an updated summary of valid tribes and their generic contents. Occasional Papers, Museum of Texas Tech University 338:1-24.

Steppan, S. 1995. Revision of the tribe Phyllotini (Rodentia: Sigmodontinae), with a phylogenetic hypothesis for the Sigmodontinae. Fieldiana Zoology, n.s., 80:1- 112.

Teta, P., A. M. Abba, G. H. Cassini, D. A. Flores, C. A. Galliari, S. O. Lucero, y M. Ramírez. 2018. Lista revisada de los mamíferos de Argentina. Mastozoología Neotropical 25:163-198.

Teta, P., y G. D'Elía. 2017. Taxonomic notes on the longclawed mole mice of the genus Geoxus (Cricetidae), with the description of a new species from an oceanic island of southern Chile. Hystrix, The Italian Journal of Mammalogy, 26. DOI: https://doi.org/10.4404/hystrix-27.2-11996.

Teta, P., G. D’Elía, C. Lanzone, A. OJeda, A. Novillo, y R. A. OJEDA. 2021. A reappraisal of the species richness of Euneomys Coues 1874 (Rodentia, Cricetidae), with emendations of the type localities of Reithrodon fossor Thomas 1899 and Euneomys mordax Thomas 1912. Mammalia. https://doi.org/10.1515/mammalia-2020-0157.

Teta, P., C. Cañón, B. D. Patterson, y U. F. J. Pardiñas. 2017. Phylogeny of the tribe Abrotrichini (Cricetidae, Sigmodontinae): integrating morphological and molecular evidence into a new classification. Cladistics 33:153-182.

Verde Arregoitia, L. D., y G. D’Elía. 2020. Classifying rodent diets for comparative research. Mammal Review 51:51-65.

Voss, R.S. 1988. Systematics and ecology of ichthyomyine rodents (Muroidea): patterns of morphological evolution in a small adaptative radiation. Bulletin of the American Museum of Natural History 2:259-493.

WeKsLeR, M. 2006. Phylogenetic relationships of the oryzomine rodents (Muroidea: Sigmodontinae): separate and combined analyses of morphological and molecular data. Bulletin of the American Museum of Natural History 296:1-149.

Weksler, M., A. R. Percequillo, y R. S. Voss. 2006. Ten new genera of Oryzomyine Rodents (Cricetidae: Sigmodontinae). American Museum Novitates 3537:1-29.

YePES, J. 1935a. Epítome de la sistemática de los roedores argentinos. Revista del Instituto Bacteriológico 7: 213-269. YEPES, J. 1935b. Consideraciones sobre el género Andinomys (Cricetinae) y descripción de una forma nueva. Anales del Museo Nacional Buenos Aires 38:333-348. 
Associated editor: Guillermo D'Elía

Submitted: January 12, 2021; Reviewed: March 24, 2021.

Accepted: May 26, 2021; Published on line: July 3, 2021. 